\title{
Description of a new species of cryptic snubnose darter (Percidae: Etheostomatinae) endemic to north-central Mississippi
}

\author{
Ken A Sterling ${ }^{\text {Corresp., } 1}$, Melvin L Warren, $\mathbf{J r}{ }^{1}$ \\ ${ }^{1}$ USDA Forest Service, Southern Research Station, Stream Ecology Laboratory, Oxford, Mississippi, United States of America \\ Corresponding Author: Ken A Sterling \\ Email address: kenneth.a.sterling@usda.gov
}

Many subclades within the large North American freshwater fish genus Etheostoma (Percidae) show brilliant male nuptial coloration during the spring spawning season. Traditionally, perceived differences in color were often used to diagnose closely related species. More recently, perceived differences in male nuptial color have prompted further investigation of potential biodiversity using genetic tools. However, cryptic diversity among Etheostoma darters renders male nuptial color as unreliable for detecting and describing diversity, which is foundational for research and conservation efforts of this group of stream fishes. Etheostoma raneyi (Yazoo Darter) is an imperiled, range-limited fish endemic to north-central Mississippi. Existing genetic evidence indicates cryptic diversity between disjunctly distributed E. raneyi from the Little Tallahatchie and Yocona river watersheds despite no obvious differences in male color between the two drainages. Analysis of morphological truss and geometric measurements and meristic and male color characters yielded quantitative differences in E. raneyi from the two drainages consistent with genetic evidence. Morphological divergence is best explained by differences in stream gradients between the two drainages. Etheostoma faulkneri, the Yoknapatawpha Darter, is described as a species under the unified species concept. The discovery of cryptic diversity within E. raneyi would likely not have occurred without genetic tools. Cryptic diversity among Etheostoma darters and other stream fishes is common, but an overreliance on traditional methods of species delimitation (e.g., identification of a readily observable physical character to diagnose a species) impedes a full accounting of the diversity in freshwater fishes in the southeastern United States. 
1 Description of a New Species of Cryptic Snubnose Darter (Percidae:

2 Etheostomatinae) Endemic to North-Central Mississippi

3 Ken A. Sterling ${ }^{1 *}$ and Melvin L. Warren, $\mathrm{Jr}^{1}$.

4

$5{ }^{1}$ USDA Forest Service, Southern Research Station, Stream Ecology Laboratory, 1000 Front

6 Street, Oxford, MS 38655, USA

$7 \quad$ *corresponding author: kenneth.a.sterling@usda.gov

8

9

10

11

12

13

14

15

16

17

18

19

Peer) reviewing PDF | (2020:04:48367:1:2:NEW 22 Jul 2020) 


\section{Introduction}

Etheostoma raneyi Suttkus and Bart (Yazoo Darter) is most closely related to other snubnose darters in western Tennessee and Kentucky and Alabama (unranked clade name Adonia, sensu Near et al., 2011) (Kozal et al., 2017). The species is distributed across small tributaries of the Little Tallahatchie (L.T.R.) and Yocona rivers (Y.R.) of north-central Mississippi in the upper Yazoo River basin (Figure 1). Etheostoma raneyi avoids the bottomland streams of the Mississippi Alluvial Plain and is limited to relatively higher-gradient, perennial streams draining sandy geologic formations of the Upper Gulf Coastal Plain (Stephenson et al., 1928; Randolph \& Kennedy, 1974; Thompson \& Muncy, 1986; Suttkus et al., 1994; Thompson, 2011; Sterling et al., 2013).

$$
\text { A phylogenetic study of Coastal Plain snubnose darters in western Tennessee and Kentucky, }
$$
and northern Mississippi, including E. raneyi, uncovered substantial genetic structure within and among species that was attributed to watershed configurations and the location of stream confluences between large drainages within the unfavorable lowland habitat of the Lower Gulf Coastal Plain and Mississippi Alluvial Plain (Powers \& Warren, 2009; Keck \& Etnier, 2005) (Figure 1). Etheostoma raneyi from the L.T.R. and Y.R. drainages were recovered as reciprocally monophyletic lineages, indicating that individuals from each drainage were evolutionarily divergent and distinct (Powers \& Warren, 2009). A more recent phylogenetic analysis using two genes and greater number of samples from across the range of the species also indicated that $E$. raneyi in the two drainages were independently evolving metapopulations (Sterling et al., 2020). Estimated time since divergence (0.4-0.8 my) was similar to estimates for snubnose darters in western Tennessee and Kentucky (Kozal et al., 2017). 
42 The original description of E. raneyi did not indicate any geographic variation in appearance,

43 male nuptial color, morphology, or meristics except for modal lateral-line scale counts between

44 the L.T.R. and Y.R. (Suttkus et al., 1994). However, an examination of standard lengths (SL)

45 between drainages showed that males and females from the Y.R. were longer compared with

46 males and females from the L.T.R. (Sterling et al., 2013). Because the available evidence

47 suggested possible differences in meristic and morphological characters and because the genetic

48 evidence indicated that E. raneyi in the Y.R. were distinct, we investigated possible differences

49 in male nuptial color, meristic characters, and morphology. The description of the new species

50 presented here is based on published data and our new analyses.

\section{Materials and Methods}

53 This study was conducted with the approval of the University of Mississippi IACUC Committee 54 (protocol 09-027), using annual collection permits issued to us from the Mississippi Museum of 55 Natural Science (Mississippi Department of Wildlife, Fisheries, and Parks) for the years 2009562014 and 2017-2018 (permit numbers: 0604091, 0513101, 0624112, 0622122, 0602132 ,

57 0610142, 0715163, 1010173).

Male nuptial color

We examined male nuptial color by taking photographs of mature, live fish in the field. Males were captured by seine and deposited into a water-filled, opaque black bucket with a lid and supplemental oxygen (a bubbler) to prevent stress and subsequent loss of color. We used a small, clear Plexiglas photarium with a white foam squeeze plate to obtain images of a lateral view of

64 the entire individual. We made all photographs using an Olympus Stylus TG-3 camera. Though 
65

66

67

one of us (K.S.) edited images for brightness and contrast, no alterations were made to hue or saturation. We made collections from February to April 2017 and March to April 2018 when males are at the peak of nuptial color (Table 1). We made a total of seven collections from six streams in the L.T.R. drainage $(n=46)$ and eight collections from five streams in the Y.R. drainage $(n=33)$. With the exception of male type specimens collected in 2018, all fishes were released after photographing them (see details under the Taxonomy subheading) We used resulting images to characterize colors and pigment patterns.

\section{To assess possible color and pigment pattern differences between drainages following} preliminary comparisons by one of us (K.S.), we asked three colleagues to score images of darters (see Supplement for data) for three characters: 1) the presence and density of black pigment in the pelvic and median fins, breast, branchiostegal membranes, chin, opercle, and cheek, which were scored as $1=$ little pigment, 2 = moderate pigment, 3 = heavy pigment; 2 ) the presence and density of blue pigment in the same areas as for black pigment, which were scored identically; 3) presence of a clear window in the anal fin scored as $1=$ window is small to nonexistent and covers $\leq 3$ membranes, blue pigment mostly extends to the belly, $2=$ window is large and covers $\geq 3$ membranes, blue pigment mostly does not extend to the belly.

Images were presented in random order and with no information on the location from which they were sampled. We compiled the scores across all three surveys, and we calculated means and $95 \%$ confidence intervals of scores for each drainage. Because this artificially reduces variance, we also present the results from each individual survey in the Supplement. Lastly, we also calculated the proportion of males having orange pigment in the anal fin from each drainage. 
88 We counted meristic characters following the methods of Hubbs \& Lagler (2004) except we

89 counted transverse scales from the origin of the anal fin diagonally toward the base of the

90 spinous dorsal fin (Page, 1983). For comparison, we compiled meristic data for closely related

91 Adonia snubnose darters (Near et al., 2011) from several sources in the literature (Bailey \&

92 Etnier, 1988; Powers \& Mayden, 2003; Kozal et al., 2017). Counting methods were clearly

93 different for one source (Kozal et al., 2017) compared with our methods and other data sources

94 as evidenced by differences in modal counts that were consistently either one count higher or

95 lower. In one instance (second dorsal fin rays) this difference in method was cited in the text. We

96 adjusted counts for consistency with other sources of data, except for caudal peduncle scales

97 because of small sample size and no clear modal count.

98 We made morphometric truss measurements following Hubbs \& Lagler (2004) and

99 Humphries et al. (1981) (Figure 2). We measured distances between 28 pairs of points (digital

100 calipers, nearest $0.1 \mathrm{~mm}$ ) and converted them to thousandths of SL to remove the effects of

101 differences in length (Grabowski et al., 2018). We assessed distributions of each variable in PC-

102 Ord ver. 6.21 (McCune \& Mefford, 2011) and, as expected, variables had little skew and roughly

103 normal distributions. We then estimated means and $95 \%$ confidence intervals for each variable

104 using resampling with replacement and 10,000 samples (Statistics.com LLC, 2009). Specimens

105 were primarily from our own collections now deposited with the National Museum of Natural

106 History (Washington, D.C.) (USNM) or the Mississippi Museum of Natural Sciences (Jackson,

107 MS) (MMNS). We obtained additional specimens from Tulane University Biodiversity Research

108 Institute (Belle Chasse, LA) (TU). Etheostoma raneyi matures at about 28-30 mm SL (Suttkus et

109 al., 1994), so we only used specimens $>30 \mathrm{~mm}$ SL. 
We used photographs of individual fish to perform geometric morphometric analyses (GMA)

111 (Klingenberg 2011) to test for and describe differences in shape between E. raneyi in the L.T.R.

112 and Y.R. We chose to use this approach rather than more traditional multivariate analysis of

113 linear truss measurements (e.g., Suttkus et al. 1994) because GMA describes changes in shape

114 among all landmark points simultaneously and produces clear graphics of shape changes and

115 effect sizes (e.g., misclassification tables) among groups (Bookstein, 1991; Parsons et al., 2003;

116 Klingenberg, 2013).

117 GMA requires images of each specimen, and a set of uniform landmark points plotted on each 118 image before analysis. We photographed the lateral view of the left side of the entire fish using

119

120

121

122

123

124 an Olympus Stylus TG-3 camera mounted on a vertical camera stand. A glass plate was placed on top of the fish to reduce curvature. Each image included a specimen ID label and a scale (mm). We imported images into tpsUtil (ver. 1.74, Rohlf, 2017a) and tpsDig (ver. 2.30, Rohlf, 2017b) software. We plotted, scaled, and digitized landmarks to produce Cartesian grid coordinates for each individual using 19 homologous landmarks (Figure 3). Because preserved specimens are often vertically curved, we used tpsUtil (ver. 1.74, Rohlf, 2017a) to straighten landmark coordinates along the midline of the body.

We imported output from the tps software into MorphoJ software for all subsequent analyses (Klingenberg; 2011, 2018). We compared shapes for males and females between drainages and compared shapes between sexes within each drainage (L.T.R. and Y.R.) (Table 2).

We used the outlier function in MorphoJ to remove individuals that may have biased the results and performed a least-squares full procrustes superimposition to remove bias resulting from differences in position and orientation among individuals (Mitteroecker \& Gunz, 2009; Klingenberg, 2011; Klingenberg \& Marugán-Lobón, 2013). Pooled within-group multivariate 
133 regression of shape data (Procrustes coordinates) against $\log _{10}$ centroid size removed possible

134 bias resulting from ontogenetic allometry; we used the resulting residual shape variation for all

135 subsequent analyses in MorphoJ (Loy et al., 1998; Klingenberg, 2011). We used discriminant

136 analysis (DA) to test for differences in shape for all comparisons. We estimated mean Procrustes

137 distance (PD) and Mahalanobis distance (M) for each comparison and ran a permutation test

$138(10,000$ permutations $)$ to estimate $\mathrm{p}$-values. We used cross-validated classification tables to

139 assess the reliability of the DA results and produced shape change graphics from DA output for

140 all comparisons.

141 Preliminary results indicated shape changes between drainages that suggested possible

142 differences in stream gradients. Therefore, we calculated watershed area $\left(\mathrm{km}^{2}\right)$ and stream

143 gradient (relief/length of stream) for all streams with Yazoo Darters in each drainage using

144 DeLorme Topo USA ver. 7.1.0 (2007) and estimated means. We used resampling with

145 replacement to calculate 95\% confidence intervals of mean values using Resampling Stats ver.

1464.0 (Statistics.com LLC, 2009).

147 We evaluated all data and results from analyses under the unified species concept which

148 recognizes that all species concepts attempt to define independently evolving metapopulations

149 but use different methods for doing so (de Queiroz, 2007). The concept provides a useful

150 framework for species delimitation by allowing evaluation of alternate hypotheses using all

151 available evidence and recognizing that the emergence of diagnostic characters (e.g., genetic,

152 morphological, or behavioral) among independently evolving lineages may or may not occur,

153 thus accommodating cryptic diversity (see Love Stowell et al., 2018).

154 Data used for GMA (MorphoJ) are available from the open access MorphoBank (O’Leary \&

155 Kaufman 2012) data repository at 
156 https://morphobank.org/index.php/MyProjects/List/select/project_id/3712. Fishes examined for

157 the truss morphological measurements were borrowed from the Tulane University Biodiversity

158 Research Institute (Belle Chasse, LA) (TU) or were from our own collections now archived at

159 the National Museum of Natural History (Washington, D.C.) (USNM) and the Mississippi

160 Museum of Natural Sciences (Jackson, MS) (MMNS). Images used for male nuptial color

161 comparisons are available in the Supplement.

162 The electronic version of this article in Portable Document Format (PDF) will represent a

163 published work according to the International Commission on Zoological Nomenclature (ICZN),

164 and hence the new name contained in the electronic version are effectively published under that

165 Code from the electronic edition alone. This published work and the nomenclatural acts it

166 contains have been registered in ZooBank, the online registration system for the ICZN. The

167 ZooBank LSIDs (Life Science Identifiers) can be resolved and the associated information viewed

168 through any standard web browser by appending the LSID to the prefix http://zoobank.org/. The

169 LSID for this publication is: urn:1sid:zoobank.org:pub:6C5BEC69-22A1-4008-84D3-

170 CA62719AE152. The online version of this work is archived and available from the following

171 digital repositories: PeerJ, PubMed Central and CLOCKSS.

173 Results

174 Male nuptial color

175 Preliminary examination of photographed male darters indicated that possible color or pigment 176 pattern differences were subtle and appeared limited to: 1) generally more extensive and denser

177 black pigment in the pectoral and median fins and the breast, cheek, opercle, and ventral portion 178 of the head region for individuals sampled in the L.T.R.; 2) generally more extensive and denser 
179 blue pigment in the same areas for individuals from the Y.R.; 3) complete absence or a small

180 clear window in the anal fin for fish from the Y.R. compared with windows always being present

181 and larger in the L.T.R.; 4) orange pigment occasionally present in the anal fin of fish from the

182 L.T.R. and never present in fish from the Y.R. (Figure 4).

183 Independent scoring of these features revealed that these average differences are consistent

184 between the drainages (Figure 5). Blue pigment was more dense and extensive in the Y.R. males, 185 but black pigment was generally more dense and extensive in the L.T.R. males. Clear windows 186 in the anal fin were generally smaller or absent in the Y.R. individuals (Figure 4). Orange

187 pigment in the anal fin was not found in fish from the Y.R., but was present in $17.7 \%$ of 46 188 males from four of six streams sampled in the L.T.R.

\section{Meristics and truss measurements}

191

192

193

194

195

196

197

198

199

200

201

Count data for lateral-line scales show a bimodal distribution that differ by two scales between individuals from the Y.R. and L.T.R. (Table 3), which is consistent with the counts of Suttkus et al. (1994). There are no other modal differences between the Y.R. and the L.T.R. drainages (Tables 4-9).

Mean proportional values for truss measurements indicate that individuals from the Y.R. are more robust with shorter heads and snouts relative to individuals from the L.T.R. Dorsal fins are also longer in the Y.R., but gape width and the position of the mouth relative to the tip of the snout shows no difference. Females in the L.T.R. have a wider inter-orbital width, but females in the Y.R. had a wider body at the pectoral fin insertion. Overall, 13 of 29 characters did not have overlapping 95\% CIs for at least one sex between drainages. Mean SL for both males and females in the Y.R. is longer than for males and females in the L.T.R. (Table 10). 
204 The outlier function in MorphoJ identified two females and two males in the L.T.R. as

205 potentially biasing results and these were removed. No individuals from the Y.R. were identified 206 as possible outliers.

207 There were significant differences in shape between females in the L.T.R. $(\mathrm{n}=51)$ and Y.R. $208(\mathrm{n}=60)$ drainages $(\mathrm{DA}, \mathrm{PD}=0.014, \mathrm{p}<0.0001 ; \mathrm{M}=3.59, \mathrm{p}<0.0001)$. Classification of

209 specimens to groups shows that $12 \%$ of individuals from the L.T.R. were incorrectly assigned to 210 the Y.R. drainage and 17\% of individuals from the Y.R. were incorrectly assigned to the L.T.R. 211 drainage. Yocona River females had shorter snouts and heads (points 4 and 16), greater body 212 depth, longer second dorsal fin (point 7), longer anal fin associated with an anterior shift in the 213 insertion (point 12), and the posterior edge of the hypural plate shows a shift anteriorly (Figure $2146)$.

215 There were significant differences in shape between males in the L.T.R. $(\mathrm{n}=50)$ and Y.R. (n $216=49)(\mathrm{DA}, \mathrm{PD}=0.009, \mathrm{p}<0.0001 ; \mathrm{M}=2.78, \mathrm{p}<0.0001)$. Classification of specimens to groups 217 shows that $32 \%$ of individuals from the L.T.R. were incorrectly assigned to the Y.R. and $29 \%$ of 218 individuals from the Y.R. were incorrectly assigned to the L.T.R. Shape changes between 219 drainages show that Y.R. males had shorter snouts and heads (points 4 and 16), greater body 220 depth, and longer second dorsal fins (point 7) (Figure 6).

221 There were significant differences in shape between males $(\mathrm{n}=50)$ and females $(\mathrm{n}=51)$ 222 within the L.T.R. drainage (DA, $\mathrm{PD}=0.015, \mathrm{p}<0.0001 ; \mathrm{M}=3.05, \mathrm{p}<0.0001)$. Classification of 223 specimens to groups shows that $20 \%$ of females were incorrectly classified as males and $25 \%$ of 224 males were incorrectly classified as females. Relative shape changes between males and females 
225 show that females are thinner with longer caudal peduncles, the insertion of the pectoral and

226 pelvic fins shifted anteriorly, and the insertion of the anal fin shifted posteriorly relative to males

227 (Figure 7).

228 There were also significant differences in shape between males $(n=49)$ and females $(n=60)$

229 within the Y.R. drainage (DA, $\mathrm{PD}=0.013, \mathrm{p}<0.0001 ; \mathrm{M}=4.63, \mathrm{p}<0.0001)$. Cross-validated

230 classification of specimens to groups shows that $3 \%$ of females were incorrectly classified as

231 males and 5\% of males were incorrectly classified as females. Relative shape changes between

232 males and females show that females are thinner, the snout is shorter, the anal and second dorsal

233 fins are shorter, the insertion of the pectoral and pelvic fins shifts anteriorly, and the insertion of

234 the anal fin shifts posteriorly relative to males (Figure 7).

235 Comparison of watershed area and stream gradients between drainages show that E. raneyi in

236 the L.T.R. mostly occur in larger streams with lower gradients compared with the Y.R. (Figure 8,

237 Table S1). Mean watershed area is more than twice as large in the L.T.R., and mean gradient is

238 about $45 \%$ greater in the Y.R. drainage. Confidence intervals do not overlap for area or gradient.

240 Taxonomy and Synonymy

241

242 Etheostoma faulkneri Sterling and Warren, Yoknapatawpha Darter (Figure 4)

243 urn:1sid:zoobank.org:act:B9FE97A8-A86C-41A9-9CD6-2929362E0C22

244

245 Etheostoma (Ulocentra) sp. Bouchard, 1974: 41 (distribution). 
247 Etheostoma sp. Clemmer et al., 1975: 8 (listing of an undescribed species of darter in the upper

248 Yazoo River basin, categorized as rare). Jenkins, 1976: 644 (listing of an undescribed 249 species, distribution).

250

251

252

253

254

255

256

257

258

259

260

261

262

263

264

265

266

267

268

269

Etheostoma (Ulocentra) sp. Kuehne \& Barbour, 1983: 99-100 (brief characterization of the "Yazoo Darter" and distribution). Knight \& Cooper, 1987: 31-32 (brief description of watershed-scale habitat before additional extensive habitat alteration), 36 (brief description of meso-habitat and distribution within the Otoucalofa Creek drainage), Table 1 (occurrence record).

Etheostoma sp. Page \& Burr, 1991: 302, pl. 43, map 345 (brief characterization of the "Yazoo Darter" and distribution.

Etheostoma raneyi, Suttkus et al., 1994: 98-109 (distribution, habitat, description of male and female color, pigment patterns, meristic characters, and morphological measurements subsumed under the description of Etheostoma raneyi), fig. 8 (ordination of morphometric data), fig. 9 (distribution). Johnston \& Haag, 1996: 47-60 (life history, distribution). Ross \& Slack, 2000: 1 (conservation status, distribution), fig. 1 (distribution), fig. 4 (photograph of a male Yazoo Darter from an unknown location). Ross, 2001: 483-484 (distribution and general description and life history account, conservation status). Adams \& Warren, 2005: fig. 4 (scatterplot showing post-drought CPUE and immigration probabilities in stream reaches that went dry during an extended drought), Appendix 1 (list of immigration probabilities and standard deviation). Powers \& Warren, 2009 (phylogeography and 
270

271

272

273

274

275

276

277

278

279

280

281

282

283

284

285

286

287

288

289

290

291

292

distribution). Near et al., 2011: fig. 3c (phylogenetic relationships among darters), fig. 4 (phylogenetic classification among darters). Page \& Burr, 2011: 558, pl. 49 (brief characterization of the "Yazoo Darter" and distribution). Schaefer et al., 2012: Appendix (occurrence and abundance). Sterling et al., 2012: 859-872 (population genetics and effects of habitat alteration on gene flow). Sterling et al., 2013: 816-842 (distribution, abundance, life history, and conservation assessment). Kozal et al., 2017: Table 1 (collection data), Table 4-10 (meristic data), 279, Table 11, and fig. 7 (results from meristic analyses), 279, fig. 5, (phylogenetic results). Sterling \& Warren, 2017: 1223-1235 (microhabitat use). Sterling et al., 2020.

Holotype: Adult male, USNM439004 (Figure 4), $43.3 \mathrm{~mm} \mathrm{SL}$, Morris Creek, tributary to the Yocona River (Upper Yazoo River system) at County Road 321, $9.28 \mathrm{~km}$ south of the Lafayette County courthouse in Oxford (34.283, -89.544), Lafayette County, MS, 1 April 2018, B.D.

Sterling, K.A. Sterling, and W.M. Sterling.

Allotype: Adult female, USNM439005 (Figure 4), $41.2 \mathrm{~mm} \mathrm{SL}$, collected with the holotype.

Paratopotypes: USNM439006 (1 male), collected with the holotype; USNM439007 (2 males, 1 female), 10 April 2014, Morris Creek at the holotype location; MMNS80818 (4 males), 22 April 2014, Morris Creek at the holotype location.

Paratypes: MMNS80819 (2 males, 4 females), 11 June 1999, Pumpkin Creek at County Road 266, Lafayette County, Mississippi, 12.5 km E of Oxford ; MMNS80820 (2 males, 5 females), 9 
293 June 1999, Yellow Leaf Creek on private property, Lafayette County Mississippi, $6.5 \mathrm{~km}$ E of 294 Oxford; MMNS80821 (1 male, 3 females), 10 April 2014, Gordon Branch at CR 121, Yalobusha 295 County, Mississippi, 7.6 km ESE of Water Valley; MMNS80822 (1 female), 10 April 2014, 296 Johnson Creek at County Road 436, Yalobusha County, Mississippi, 3.9 km S of Water Valley; 297 MMNS80823 (4 males), 21 April 2014, Gordon Branch at CR 121, Yalobusha County, 298 Mississippi, 7.6 km ESE of Water Valley; MMNS80824 (5 males, 1 female), 22 April 2014, Mill 299 Creek at State Highway 315, Yalobusha County, Mississippi, 5.7 km WSW of Paris; 300 MMNS80825 (3 males, 2 females), 12 October 2017, Splinter Creek at State Highway 328, 301 Lafayette County, Mississippi, 8.9 km N of Water Valley; USNM439008 (2 males, 4 females), 302 12 October 2017, Splinter Creek at County Road 348, Lafayette County, Mississippi, 10 km N of 303 Water Valley; MMNS80826 (4 females, 1 juvenile), 9 June 1999, Yellow Leaf Creek on private 304 property downstream of a confluence with an unnamed tributary, Lafayette County, Mississippi, $8.2 \mathrm{~km}$ E of Oxford and 16.3 km SSE of Abbeville; TU152109 (4 males, 6 females), 11 May 306 1988, un-named tributary to Taylor Creek at Old Taylor Road, Lafayette County, Mississippi, 2.7 km N of Taylor; TU3116 (5 males, 6 females), 24 May 1952, Pumpkin Creek at State Highway 6, Lafayette County, Mississippi, 12 km ESE of Oxford; TU155210 (6 males, 15 County, Mississippi, 4.2 km SSE of Water Valley; TU155225 (1 males, 2 females), 15 June 
315 Etheostoma faulkneri is one of at least 27 species, undescribed forms, or Evolutionary

316 Significant Units of snubnose darters in the unranked clade Adonia (sensu Near et al., 2011; see

317 Blanco, 2001; Brogdon et al., 2003; Boschung \& Mayden, 2004; Gabel, 2007; Kozal et al., 2017)

318 (Table S2) and is indicated as the sister species of E. raneyi (Sterling et al., 2020). Consistent

319 with other Adonia snubnose darters, E. faulkneri lack a frenum and usually have several long,

320 thin teeth on the vomer (Suttkus et al., 1994; Kozal et al., 2017). Modal lateral line scale counts

321 differ between E. faulkneri (45) and E. raneyi (47). Etheostoma faulkneri males and females

322 have shorter snouts and heads and more robust bodies relative to E. raneyi and are longer.

323 Compared with E. raneyi, male E. faulkneri usually have a smaller or no clear window in the

324 blue anal fin and more extensive blue pigment on the anal fin, second dorsal fin, procurrent rays

325 of the caudal fin, the cheek, opercle, and tip of the snout during the spawning season.

326 Etheostoma faulkneri also lack orange pigment in the anal fin which is present in a small

327 proportion (17.7\%) of male E. raneyi, and the black pigment on the opercle, cheek, chin,

328 branchiostegal rays, pelvic fins, second dorsal fin, and caudal fin is generally less dense and less

329 extensive for E. faulkneri than for E. raneyi. This results in spawning male E. faulkneri usually

330 appearing brighter blue than E. raneyi, which appear duskier (Figure 4).Etheostoma faulkneri

331 can be distinguished from E. raneyi by fixed allele differences at 12 loci on the mitochondrial

$332 c y t b$ gene and one difference and two deletions on the nuclear $S 7$ gene (Sterling et al., 2020). 333

334 Description

335 Maximum length for E. faulkneri is a $64 \mathrm{~mm}$ SL male sampled from Morris Creek. For females, 336 three $49 \mathrm{~mm}$ SL individuals were each sampled from Yellow Leaf, Johnson, and Morris creeks. 
337 Maximum SL for E. raneyi is $57 \mathrm{~mm}$ for males and $50 \mathrm{~mm}$ for females (K. Sterling, 2011-2019,

338 personal observations).

339 The lateral line is complete with 41-51 scales (mode $=45)$ (Table 3$)$. The last scale is

340 sometimes unpored. Transverse scales range from 11-15 (mode $=13)($ Table 4$)$, and scales

341 around the caudal peduncle range from 16-19 $($ mode $=17)($ Table 5$)$. Dorsal fin spines range

342 from 9-11 $($ mode $=10)$, second dorsal fin rays range from 9-11 $($ mode $=11)($ Tables $6-7)$, anal

343 fin rays range from 6-8 (mode $=7)$, and pectoral fin rays range from 13-15 $($ mode $=14)($ Tables

344 8-9). The belly, nape, cheek, and opercle are scaled, and the breast is usually naked but

345 frequently has several scales, especially for large individuals. The prepectoral area is often

346 scaled, but for some individuals scales are limited in extent.

347 The spinous dorsal fin of male E. faulkneri has a bright turquoise margin, an incomplete

348 medial band of bright red in the posterior 3-5 interradial membranes that fades anteriorly into a

349 metallic gold color best seen against a black background but appears as beige patches of pigment

350 against light backgrounds (described as pale cream in Suttkus et al., 1994). A band of black that

351 is usually incomplete is basal to the red and gold band and is present in the anterior 1-6 fin

352 membranes. During the spawning season, this black band is often suffused or overlain with

353 turquoise pigment. The soft dorsal fin margin has a diffuse posterior patch of turquoise; the

354 turquoise pigment becomes limited to the fin rays anteriorly and does not compose a band of

355 color ( we did not observe a band of turquoise in the soft dorsal fin as described in Suttkus et al.,

3561994 for either E. raneyi or E. faulkneri). A bright orange medial band of color in the interradial

357 membranes extends from the posterior edge of the soft dorsal fin and fades and becomes thinner

358 anteriorly through 5-8 membranes. A basal patch of black pigment often occurs where the fin

359 meets a dorsal saddle. Black pigment is frequently present in the interradial membranes of the fin 
360 but is usually less dense and less extensive in area compared with E. raneyi, though in some 361 individuals the black pigment is well developed.

362 The anal and pelvic fins are bright turquoise in nuptial males. A small, thin, clear to creamy

363 medial window in the anal fin is often present in the posterior 2-3 interradial membranes.

364 Turquoise pigment is well developed from the margin of the anal fin to the belly. In contrast, $E$.

365 raneyi usually have larger windows that cover 3-4 membranes and are wider. In some

366 individuals, black pigment is present in the membranes of the pelvic fins, which is usually denser

367 and more extensive in E. raneyi. The pectoral fins of E. faulkneri are mostly devoid of pigment, 368 but the rays have intense orange pigment proximal to the fin insertion. The caudal fin is mostly clear, but the procurrent rays of nuptial males are bright turquoise blue, and the primary rays may

370 have some green, blue, or black pigment.

371 The background color of adult males is a warm cream color dorsally that becomes paler

372 ventrally. Large males have intense dark orange pigment from the mid-ventral area up to the 373 mid-lateral stripe that fades to a lighter, bright orange anteriorly. In some males, the orange is

374 also present in the prepectoral area. In small males, the orange is reduced to a band of pigment 375 along the side of the belly that does not extend to the mid-lateral stripe or to the anal fin. Two 376 basicaudal spots of orange are almost always present. The mid-lateral stripe consists of a series 377 of blotches bisected by a depigmented lateral line that becomes indistinct posteriorly. Blotches 378 alternate between a dark brown to black color and a dark red color. The dark red blotches are usually elongate rectangles. The dark brown or black blotches are often the ventral portion of a y-shaped pattern that extends to the dorsal fins and is connected by the dorsal saddles, of which

381 there are eight (see Figure 4). However, these blotches are irregularly shaped and patterns are 382 often irregular, especially anteriorly. The dark brown and black pigment becomes an irregular 
383 series of spots and blotches on the head. A dark to dusky suborbital bar extending below the eye

384 is usually present as is a dark pre-orbital stripe. The top of the head is the same dark brown as the

385 dorsal saddles. In nuptial males, there may be green to turquoise tint to the top of the head and

386 anterior saddles as well as the tip of the snout. A clear, bright turquoise color is present on the

387 pre-opercle, opercle, cheek, chin, branchiostegal rays, and breast. In some individuals, black

388 spots of pigment are present in these areas which cause the bright turquoise to appear dusky, an

389 effect more often seen in E. raneyi.

390 Females are more cryptically colored although the pigment patterns of the mid-lateral stripe 391 and dorsal surface of the body are highly similar to the male. The background color is a neutral

392 tan dorsally and becomes an unsullied bright white ventrally. The mid-lateral stripe is an

393 alternating series of dark maroon to warm brown and dark brown to black blotches bisected by

394 an unpigmented lateral line that becomes more indistinct posteriorly. The maroon or warm

395 brown blotches are elongate rectangles, and the dark brown to black blotches are usually

396 irregular in size and shape, sometimes connected to the dorsal saddles. Blotches become more

397 irregular anteriorly and are small on the head and opercle. A dark to dusky pre-orbital stripe and

398 suborbital bar usually are present. The belly is usually devoid of pigment, though large females

399 may have some small spots of orange pigment. Two orange basicaudal spots are almost always

400 present. In nuptial females, a light wash of turquoise may occur on the breast, tip of the snout,

401 and top of the head. Fins are all mostly devoid of bright pigment with clear membranes and a

402 series of elongate dark brown to black areas of pigment on the straw-colored dorsal and caudal

403 fin rays. Occasionally, the red median band in the spinous dorsal fin of males is present in

404 females though the color is much less intense and often appears as an indistinct series of spots in 
405 the most posterior 1-3 membranes. The pelvic, pectoral, and anal fins are usually clear though an

406 indistinct wash of turquoise may be present in the anal fin.

407

408 Distribution: Etheostoma faulkneri is endemic to perennial headwater tributaries of the Y.R.

409 drainage. To the east, distribution appears limited by the increased presence of intermittent

410 streams in terrain with less relief and more extensive agricultural land (Figure 1). Otoucalofa

411 Creek, a large tributary to the Y.R., may have the largest connected population of E. faulkneri

412 (Sterling et al,; 2012, 2013). The species is known from 33 sites in 20 streams; 11 streams are in

413 the Otoucalofa Creek system (Table S3), and future sampling will likely yield E. faulkneri in

414 several additional streams that appear to have suitable habitat. However, repeated sampling

415 indicates that E. faulkneri are uncommon in most streams of occurrence and may even be

416 extirpated from Smith Creek in Calhoun County (A. Carson, 2016-2017, personal

417 communications). The earliest known collection was by R.D. Suttkus on May 24, 1952 when 11

418 individuals were taken in Pumpkin Creek at State Highway 6, Lafayette Co., Mississippi (TU

$419 \quad 3116)$.

420

421

Habitat,biology, and population genetics

422 The biology and habitat use of E. faulkneri is apparently similar to that of E. raneyi (Knight \&

423 Cooper, 1987; Suttkus et al., 1994; Sterling \& Warren, 2017). A life history study of E. faulkneri

424 was conducted at Morris Creek (Johnston \& Haag, 1996), results of which are consistent with the

425 literature for other clade Adonia snubnose darters (Carney \& Burr, 1989; Khudamrongsawat \&

426 Kuhajda, 2007; Barton \& Powers, 2010). In our experience in the field, E. faulkneri are most

427 commonly sampled from less-disturbed small streams with strong perennial flow and plentiful 
428 instream cover (wood or hard clay riffles). In streams lacking cover because of channelization, 429 incisement, and sedimentation, the species is often collected from the rubble, wood pilings, and

430 human refuse associated with bridge crossings and is sparse elsewhere. The first known

431 description of habitat use by E. faulkneri (specific to the Otoucalofa Creek watershed) indicates

432 that the species is usually found in densely canopied first-order streams that have not been clear433 cut and are associated with hard-clay riffles (Knight \& Cooper, 1987). Genetic studies indicate 434 that E. faulkneri has lower genetic diversity relative to E. raneyi, likely suffers from decreased 435 gene flow because of anthropogenic habitat destruction and fragmentation, and effective 436 population sizes are likely dangerously low (Powers \& Warren, 2009; Sterling 2011; Sterling et 437 al. 2012; Sterling et al. 2020)

\section{Conservation management}

440 Etheostoma faulkneri is restricted to one headwater drainage in the upper Yazoo River basin with 441 a total area of only about $1500 \mathrm{~km}^{2}$ (relative to about $3200 \mathrm{~km}^{2}$ for E. raneyi) and is distributed 442 almost entirely on private lands (Sterling et al., 2013). As described earlier, the species has low 443 genetic diversity and is nowhere abundant outside of small stream reaches associated with some road crossings. Streams in western Tennessee and northern Mississippi are among the most

445 altered in the United States and suitable habitat for several imperiled snubnose darters including E. faulkneri is lacking (Shields et al., 1995; Warren et al., 2002; Keck \& Etnier, 2005; Fore et al., 447 2019). Urban development in the Y.R. drainage is increasing rapidly in association with the explosive growth of the city of Oxford and, to a lesser extent, Water Valley, MS. As a result, $E$. faulkneri faces increasing habitat degradation through time across most of its range. However,

450 the Otoucalofa Creek watershed (Figure 1) is not yet under the direct threat of increased rates of 
451 development and appears to hold the largest connected population of E. faulkneri (Sterling et al.;

452 2012, 2013). Land use is still mostly dominated by timber plantations and row crop agriculture

453 upstream of Water Valley. The United States Fish and Wildlife Service (USFWS) (Jackson, MS)

454 and United States Department of Agriculture Natural Resources Conservation Service (NRCS)

455 (Jackson, MS) have also taken steps to improve aquatic organism passage and riparian habitat in

456 two streams in the Otoucalofa Creek watershed (NRCS, 2020; USFWS, 2020). Time possibly

457 remains for the public to become aware that a unique part of their natural heritage swims in the

458 streams in their backyards, on their farms, and the lands they hunt. Increased awareness may help

459 to protect enough habitat for E. faulkneri to persist in the Otoucalofa Creek watershed over the

460 coming century.

461

462

Etymology

463 We have named the species Etheostoma faulkneri to honor the great writer and Nobel Laureate

464 William C. Faulkner (1897-1962), a native of the Oxford, Mississippi area who was also an avid

465 hunter and fisher. The landscape was an important theme in many of his works, and the actions

466 of his characters were often influenced by the lands and streams surrounding his fictional

467 Jefferson, Mississippi, including the Yocona River, which he renamed the Yoknapatawpha.

469 Discussion

470 Etheostoma faulkneri masqueraded as E. raneyi for decades mostly because of the lack of

471 distinctive color differences in nuptial males during spawning. Even so, patterns of distribution

472 (Figure 1) and quantitative differences in lateral-line scale counts (Table 3), male nuptial color

473 (Figures 4 and 5), length (Table 10), and morphology (Table 10; Figure 6) between individuals 
474 sampled from the Y.R. and L.T.R., as well as population genetic and phylogenetic data (Powers

475 \& Warren, 2009; Sterling et al.; 2012, 2020), constitute multiple lines of evidence that support

476 the recognition of Etheostoma faulkneri as a separately evolving metapopulation and valid

477 species under the unified species concept (de Queiroz, 2007).

478 The subtle differences in male nuptial color, meristics, and morphology indicated by our

479 results are similar to those found between other recently diverged pairs of snubnose darters

480 (Suttkus et al., 1994; Bauer et al., 1995; Powers \& Mayden, 2003). For example, diagnostic

481 meristic characters between E. cyanoprosopum and E. zonistium are limited to modal lateral-line

482 and transverse scale counts and male nuptial color differences are limited to the presence of a red

483 ocellus in the first interradial membrane in E. zonistium, a character that is not universal among

484 all nuptial males (K. Sterling, 2009-2020, personal observations) (Kozal et al., 2017). Another

485 recently diverged species pair, E. cervus and E. pyrrhogaster, show only a modal difference in

486 lateral-line scale counts, a tendency for nuptial males of one species to have green pigment on

487 the ventral portion of the head but the other species does not, and quantitative differences in two

488 truss measures (Powers \& Mayden 2003). Though distinct differences in male color among

489 closely related taxa are sometimes described (Boschung et al., 1992), subjective descriptions of

490 color differences are likely to vary according to the source (e.g., Boschung et al. 1992 and

491 Suttkus \& Bailey, 1993). In some cases, described differences in male color are less than distinct

492 (e.g., E. raneyi, E. ramseyi and E. lachneri; Suttkus et al., 1994) across the range of individual

493 variation within species (see Ulocentra key in Boschung \& Mayden, 2004). Qualitative

494 differences in meristic and morphological characters are rare among Adonia snubnose darters

495 and are limited to counts of branchiostegal rays which separate E. coosae from the rest of the 
496 clade (except for E. scotti, Bauer et al., 1995). Our results are consistent with these observations

497 and do not indicate any qualitative differences between E. raneyi and E. faulkneri.

498 Because pigment patterns, meristics, and body shape cannot reliably distinguish individuals

499 from the L.T.R. and Y.R., and the only diagnosable characters that qualitatively distinguish

500 between E. faulkneri and E. raneyi are genetic (Powers \& Warren, 2009; Sterling et al., 2020), it

501 is reasonable to categorize E. faulkneri as a cryptic species. Cryptic species can occur through

502 several mechanisms that are not mutually exclusive: evolutionary convergence, recent

503 divergence, and phylogenetic niche conservatism (Fišer et al., 2017). Evolutionary convergence

504 is clearly not a factor. However, the estimated time of separation between E. faulkneri and E.

505 raneyi $(<1 \mathrm{my})$ is recent (Sterling et al., 2020), and niche conservatism is apparent between the

506 two species (Johnston \& Haag, 1996; Sterling et al., 2017; Ruble et al., 2019) and other snubnose

507 darters as well (O’Neil, 1981; Carney \& Burr, 1989; Hicks, 1990; Khudamrongsawat \&

508 Kuhajda, 2007; Barton \& Powers, 2010; Hubbell \& Banford, 2019). Etheostoma faulkneri and E.

509 raneyi exist in adjacent drainages with little latitudinal gradient, no elevational gradient, and no

510 clear differences in surface geology, water chemistry, or aquatic communities. Their Eltonian

511 and Grinnellian niches appear to be identical in all respects but one: there is a small difference in

512 stream size and gradient between streams that the two species inhabit. Though this difference has

513 likely influenced the subtle morphological divergence that we detected, in the absence of other

514 biotic or abiotic differences between the L.T.R. and Y.R. drainages, stabilizing selection for their

515 ancestral niche across a short time span since separation has clearly prevented the evolution of

516 readily observable divergent morphological, meristic, or color characters.

517 Cryptic diversity is common among diverse taxa (Pfenninger \& Schwenk, 2007; Adams et al.,

518 2014; Fennessy et al., 2016), including freshwater fishes in North America (Egge \& Simons, 
519 2006; April et al., 2011). Among darters (Etheostomatinae), cryptic diversity is especially

520 common (April et al., 2011) and is linked to niche conservatism, vicariant events and allopatric

521 distributions, and relatively stable habitat conditions over geologic time-scales (Bauer et al.,

522 1995; Page et al., 2003; Near \& Benard, 2004; Hollingsworth \& Near, 2009; Kozal et al., 2017).

523 These conditions are consistent with the literature on E. faulkneri and E. raneyi and our results

524 (Johnston \& Haag, 1996; Powers \& Warren, 2009; Sterling \& Warren, 2017; Sterling et al.,

525 2020), as they are for other Adonia snubnose darters (Carney \& Burr, 1989; Bauer et al., 1995;

526 Powers \& Mayden, 2003; Khudamrongsawat \& Kuhajda, 2007; Kozal et al., 2017).

527

\section{Conclusions}

529 The results we present here, existing genetic evidence (Powers \& Warren, 2009; Sterling et al.;

5302012,2020 ), and a growing acceptance among biologists that the presence of readily observable

531 qualitative diagnostic characters are not necessary to describe biodiversity (Egge \& Simons,

532 2006; de Queiroz, 2007; Fišer et al., 2017), supports the recognition and description of

533 Etheostoma faulkneri, the Yoknapatawpha Darter, as an independently evolving metapopulation

534 lineage and valid species under the unified species concept (de Queiroz, 2007). The description

535 of E. faulkneri represents an increase in the accuracy of our understanding of freshwater fish

536 evolution and diversity, which is the foundation for research and conservation efforts for the

537 many imperiled freshwater fishes of the southeastern United States.

538

539 Acknowledgments

540 We thank the many people who contributed to this project by assisting in the field and lab,

541 sharing ideas and information, and providing logistical support: S. Adams, Z. Barnett, H. Bart, S. 
542 Bingham, M. Bland, A. Carson, W. Haag, G. Henderson, J. Hubbell, C. Jenkins, G. McWhirter,

543 S. Nielsen, B. Noonan, C. Sabatia, J. Schaefer, C. Smith, S. Smith, B. Sterling, W. Sterling, and

544 M. Wagner. This study was supported by the USDA Forest Service, Southern Research Station, 545 Oxford, MS.

546

547 Literature Cited

548 Adams, M., T.A. Raadik, C.P. Burridge and A. Georges. 2014. Global biodiversity assessment 549 and hyper-cryptic species complexes: more than one species of elephant in the room?

$550 \quad$ Systematic Biology 63:518-533.

551 Adams, S.B. and M.L. Warren, Jr. 2005. Recolonization by warmwater fishes and crayfishes

552 after severe drought in Upper Coastal Plain Hill streams. Transactions of the American $553 \quad$ Fisheries Society 134:1173-1192.

554 April, J., R.L. Mayden, R.H. Hanner and L. Bernatchez. 2011. Genetic calibration of species 555 diversity among North America's freshwater fishes. Proceedings of the National Academy of 556 Sciences 108:10602-10607.

557 Bailey, R.M. and D.A. Etnier. 1988. Comments on the subgenera of darters (Percidae) with 558 descriptions of two new species of Etheostoma (Ulocentra) from southeastern United States. 559 Miscellaneous Publications of the Museum of Zoology, University of Michigan 175:1-48. 560 Barton, S.D. and S.L. Powers. 2010. Life-history aspects of the Cherokee Darter, Etheostoma 561 scotti (Actinopterygii: Percidae), an imperiled species in northern Georgia. Southeastern $562 \quad$ Naturalist 9:687-698. 
563 Bauer, B.H., D.A. Etnier and N.M. Burkhead. 1995. Etheostoma (Ulocentra) scotti

564 (Osteichthyes: Percidae), a new darter from the Etowah River system in Georgia. Bulletin of

565 the Alabama Museum of Natural History 17:1-16.

566 Blanco, C.C. 2001. Historical ecology, land use associations, and species habitat associations of

567 the Vermilion Darter (Etheostoma chermocki) in the upper Turkey Creek watershed, tributary

568 of Locust Fork, Black Warrior River drainage, Alabama. PhD dissertation, University of

569 Alabama, Tuscaloosa, AL.

570 Bookstein, F.L. 1991. Morphometric tools for landmark data: geometry and biology. Cambridge

571 University Press, Cambridge, U.K..

572 Boschung, H.T., R.L. Mayden and J.R. Tomelleri. 1992. Etheostoma chermocki, a new species

573 of darter (Teleostei: Percidae) from the Black Warrior River drainage of Alabama. Bulletin of 574 the Alabama Museum of Natural History 13:11-20.

575 Boschung, H.T. and R.L. Mayden. 2004. Fishes of Alabama. Smithsonian Books, Washington, $576 \quad$ D.C.

577 Bouchard, R.W. 1974. The subgenus Ulocentra (Percidae: Etheostomatini) in western Kentucky, 578 western Tennessee, and northern Mississippi. Association of Southeastern Biologists Bulletin $579 \quad 21: 41$.

580 Brogdon, S.M., C.R. Tabit and L.G. Kral. 2003. Population structure of the Tallapoosa Darter 581 (Etheostoma tallapoosae). Southeastern Naturalist. 2:487-498.

582 Carney, D.A. and B.M. Burr. 1989. Life histories of the Bandfin Darter, Etheostoma zonistium, 583 and Firebelly Darter, Etheostoma pyrrhogaster, in western Kentucky. Illinois Natural History $584 \quad$ Survey Biological Notes 134:1-16. 
585 Clemmer, G.H., R.D. Suttkus and J.S. Ramsey. 1975. A preliminary checklist of endangered and 586 rare fishes of Mississippi. In: Mississippi Game and Fish Commission preliminary list of rare 587 and threatened vertebrates in Mississippi, pp. 6-11. Mississippi Department of Wildlife, $588 \quad$ Fisheries, and Parks, Jackson, MS.

589 DeLorme. 2007. Topo USA [computer program].Version 7.1.0. DeLorme, Yarmouth, ME. 590 de Queiroz, K. 2007. Species concepts and species delimitation. Systematic Biology 56:879-886. 591 Egge, J.J.D. and A.M. Simmons. 2006. The challenge of truly cryptic diversity: diagnosis and 592 description of a new madtom catfish (Ictaluridae: Noturus). Zoologica Scripta 35:581-595. 593 Fennessy, J., T. Bidon, F. Reuss, V. Kumar, P. Elkan, M.A. Nilssen, M. Vamberger, U. Fritz and 594 A. Janke. Multi-locus analyses reveal four giraffe species instead of one. Current Biology 26: $595 \quad 2543-2549$.

596 Fišer, C., C.T. Robinson and F. Malard. 2018. Cryptic species as a window into the paradigm 597 shift of the species concept. Molecular Ecology 27:613-635.

598 Fore, J.D., A.B. Alford, D.C. Blackwood and T.A. Blanchard. 2019. Linking fish trait responses 599 to in-stream habitat in reconstructed valley-plugged stream reaches of the Coastal Plain, $600 \quad$ U.S.A. Restoration Ecology 27:1483-1497.

601 Gabel, J.M.H. 2007. Microsatellite analysis of genetic population structure and gene flow in 602 populations of the Federally Threatened Cherokee Darter, Ethesotoma scotti. PhD 603 dissertation, Duquesne University, Pittsburg, PA.

604 Grabowski, T.B., J. Pease and J.R. Groeschel-Taylor. 2018. Intraspecific differences in 605 morphology correspond to differential spawning habitat use in two riverine catostomid 606 species. Environmental Biology of Fishes 101:1249-1260. 
607 Hicks, D.T. 1990. Distribution and life history aspects of the Cherry Darter, Etheostoma etnieri 608 (Osteichthyes: Percidae). M.S. thesis. Tennessee Technological University, Cookeville, TN. 609 Hollingsworth, Jr., P.R. and T.J. Near. 2009. Temporal patterns of diversification and 610 microendemism in Eastern Highland endemic barcheek darters (Percidae: Etheostomatinae). 611 Evolution 63:228-243.

612 Hubbell, J.P. and H. Banford. 2019. Microhabitat use, spawning behavior, and spawning 613 substrate use of the Tallapoosa Darter (Etheostoma tallapoosae). American Midland $614 \quad$ Naturalist 182:216-227.

615 Hubbs, C.L. and K.L. Lagler. 2004. Fishes of the Great Lakes Region, revised edition. The 616 University of Michigan Press, Ann Arbor, MI.

617 Humphries, J.M., F.L. Bookstein, B. Chernoff, G.R. Smith, R.L. Elder and S.G. Poss. 1981. 618 Multivariate discrimination by shape in relation to size. Systematic Zoology 30:291-308. 619 Jenkins, R.E. 1976. A list of the undescribed freshwater fish species of continental United States 620 and Canada, with additions to the 1970 checklist. Copeia 1976:642-644.

621 Johnston, C.E. and W.R. Haag. 1996. Life history of the Yazoo Darter (Percidae: Etheostoma 622 raneyi), a species endemic to north-central Mississippi. Tulane Studies in Zoology and 623 Botany 30:47-60.

624 Keck, B.P. and D.A. Etnier. 2005. Distributional changes of the fishes of the Hatchie River 625 system in western Tennessee and northern Mississippi. Southeastern Naturalist 4:597-626. 626 Khudamrongsawat, J. and B.R. Kuhajda. 2007. Life history of the Warrior Darter (Etheostoma 627 bellator) and comparison with the endangered Vermillion Darter (Etheostoma chermocki). 628 Journal of Freshwater Ecology 22:241-248. 
629 Klingenberg, C.P. 2011. MorphoJ: an integrated software package for geometric morphometrics.

630 Molecular Ecology Resources 11:353-357.

631 Klingenberg, C.P. 2013. Visualizations in geometric morphometrics: how to read and how to 632 make graphs showing shape changes. Hystrix 24:15-24.

633 Klingenberg, C.P. and J. Marugán-Lobón. 2013. Evolutionary covariation in geometric 634 morphometric data: analyzing integration, modularity and allometry in a phylogenetic 635 context. Systematic Biology 62:591-610.

636 Klingenberg, C.P. 2018. MorphoJ software [computer program]. Version 1.06d 637 http://www.flywings.org.uk/MorphoJ_page.htm.

638 Knight, S.S. and C.M. Cooper. 1987. Fishes of Otoucalofa Creek, Mississippi prior to major 639 channel modifications. Journal of the Mississippi Academy of Sciences 32:31-38.

640 Kozal, L.C., J.W. Simmons, J.M. Mollish, D.J. MacGuigan, E. Benavides, B.P. Keck and T.J. 641 Near. 2017. Phylogenetic and morphological diversity of the Etheostoma zonistium species 642 complex with the description of a new species endemic to the Cumberland Plateau of 643 Alabama. Bulletin of the Peabody Museum of Natural History 58:263-286.

644 Kuehne, R.A. and R.W. Barbour. 1983. The American Darters. University of Kentucky Press, 645 Lexington, KY.

646 Love Stowell, S.M., J.L. Metcalf, D.F. Markle and A.P. Martin. 2018. Species conceptualization 647 and delimitation: a framework for the taxonomic revision of Cutthroat Trout. In: Cutthroat 648 Trout: evolutionary biology and taxonomy, pp. 33-51. P. Trotter, P. Bisson, L. Schultz and B. 649 Roper, Eds. American Fisheries Society, Special Publication 36. Bethesda, Maryland. 
650 Loy, A., L. Mariani, M. Bertelletti and L. Tunesi. 1998. Visualizing allometry: morphometrics in 651 the study of shape changes in the early stages of the two-banded sea bream, Diplodus vulgaris 652 (Perciformes, Sparidae). Journal of Morphology 237:137-146.

653 McCune, B. and M.J. Mefford. 2011. PC-ORD ver. 6.21, multivariate analysis of ecological 654 data. MjM Software, Gleneden Beach, OR.

655 Mitteroecker, P. and P. Gunz. 2009. Advances in geometric morphometrics. Evolutionary 656 Biology 36:235-247.

657 Near, T.J. and M.F. Benard. 2004. Rapid allopatric speciation in Logperch darters (Percidae: 658 Percina). Evolution 58:2798-2808.

659 Near, T.J., C.M. Bossu, G.S. Bradburd, R.L. Carlson, R.C. Harrington, P.R. Hollingsworth Jr., 660 B.P. Keck and D.A. Etnier. 2011. Phylogeny and temporal diversification of darters 661 (Percidae: Etheostomatinae). Systematic Biology 60:565-595.

662 NRCS. 2020. USDA Natural Resources Conservation Service, Yazoo Darter Project. Webpage: 663 https://www.nrcs.usda.gov/wps/portal/nrcs/detail/national/plantsanimals/fishwildlife/?cid=nrc 664 seprd1302228, accessed 2-26-2020.

665 O’Leary, M.A. and S.G. Kaufman. 2012. MorphoBank ver. 3.0: web application for 666 morphological phylogenetics and taxonomy. http://www.morphobank.org.

667 O’Neil, P.E. 1981. Life history of Etheostoma coosae (Pisces: Percidae) in Barbaree Creek, 668 Alabama. Tulane Studies in Zoology and Botany 23:75-83.

669 Page, L.M. 1983. Handbook of Darters. TFH Publications, Inc, Neptune City, NJ.

670 Page, L.M. and B.M. Burr. 1991. A Field Guide to Freshwater Fishes of North America, North 671 of Mexico. Houghton Mifflin Co., Boston. 
672 Page, L.M., M. Hardman and T.J. Near. 2003. Phylogenetic relationships of barcheek darters

673 (Percidae: Etheostoma, Subgenus Catonotus) with descriptions of two new species. Copeia $674 \quad 2003: 512-530$.

675 Page, L.M. and B.M. Burr. 2011. Peterson Field Guide to Freshwater Fishes of North America, 676 North of Mexico. Houghton Mifflin Harcourt, Boston.

677 Parsons, K.J., B.W. Robinson and T. Hrbek. 2003. Getting into shape: An empirical comparison 678 of traditional truss-based morphometric methods with a newer geometric method applied to 679 New World cichlids. Environmental Biology of Fishes 67:417-431.

680 Pfenninger, M. and K. Schwenk. 2007. Cryptic animal species are homogenously distributed 681 among taxa and biogeographical regions. BMC Evolutionary Biology 7:121, 682 https://doi.org/10.1186/1471-2148-7-121.

683 Powers, S.L. and R.L. Mayden. 2003. Etheostoma cervus: A new species from the Forked Deer 684 River system in Western Tennessee with comparison to Etheostoma pyrrhogaster (Percidae: 685 Subgenus Ulocentra). Copeia 2003:576-582.

686 Powers, S.L. and M.L. Warren, Jr. 2009. Phylogeography of three snubnose darters (Percidae: 687 subgenus Ulocentra) endemic to the southeastern US Coastal Plain. Copeia 2009:523-528. 688 Randolph, K.N. and M.L. Kennedy. 1974. The fishes of the Tippah River system Mississippi, 689 with notes on habitats and distribution. Journal of the Mississippi Academy of Science $690 \quad 19: 128-134$.

691 Rohlf, F.J. 2017a. TpsUtil [computer program]. Version1.74. http://life.bio.sunysb.edu/morph/. 692 Rohlf, F.J. 2017b. TpsDig [computer program]. Version 2.30. http://life.bio.sunysb.edu/morph/. 693 Ross, S.T. 2001. Inland Fishes of Mississippi. University Press of Mississippi, Jackson, MS. 694 Ross, S.T. and W.T. Slack. 2000. Imperiled fishes in Mississippi. American Currents 26:1-5. 
695 Ruble, C.L., K.A. Sterling and M.L. Warren Jr. 2019. Captive propagation and early life history

696 of the Yazoo Darter (Etheostoma raneyi). Southeastern Naturalist 18:525-540.

697 Schaefer, J.F., S.R. Clark and M.L. Warren, Jr. 2012. Diversity and stability in Mississippi

698 stream fish assemblages. Freshwater Science 31: 882-894.

699 Shields, F.D., Jr., S.S. Knight and C.M. Cooper. 1995. Rehabilitation of watersheds with incising

700 channels. Water Resources Bulletin 31:971-982.

701 Statistics.com LLC. 2009. Resampling Stats add-in for Excel [computer program]. Version 4.0.

702 Arlington, VA.

703 Stephenson, L.W., W.N. Logan and G.A. Waring. 1928. The ground-water resources of

704 Mississippi. USGS Water-Supply Paper 576, Washington, D.C.

705 https://pubs.usgs.gov/wsp/0576/report.pdf.

706 Sterling, K.A., M.L. Warren Jr, B.P. Noonan, D.H. Reed, L.G. Henderson. 2011. Yazoo darter,

707 Etheostoma raneyi: population and demographic status, distributional changes, and habitat

708 use of an endemic, nongame species. Final report submitted to the Mississippi Museum of

$709 \quad$ Natural Science, Jackson MS.

710 Sterling, K.A., D.H. Reed, B.P. Noonan and M.L. Warren, Jr. 2012. Genetic effects of habitat

711 fragmentation and population isolation on Etheostoma raneyi (Percidae). Conservation

712 Genetics 13:859-872.

713 Sterling, K.A., M.L. Warren, Jr. and L.G. Henderson. 2013. Conservation assessment of the

714 Yazoo Darter (Etheostoma raneyi). Southeastern Naturalist 12:816-842.

715 Sterling K.A. and M.L. Warren, Jr. 2017. Microhabitat estimation of an imperiled headwater

716 fish, the Yazoo Darter (Etheostoma raneyi), in Coastal Plain streams. Environmental Biology

717 of Fishes 100:1223-1235. 
718 Sterling, K.A., S.V. Neilsen, A.J. Brown, M.L. Warren, Jr. and B.P. Noonan. 2020. Cryptic

719 diversity among Yazoo Darters (Percidae: Etheostoma raneyi) in disjunct watersheds of

720 northern Mississippi. PeerJ, in press.

721 Suttkus, R.D. and R.M. Bailey. 1993. Etheostoma colorosum and E. bellator, two new darters,

722 subgenus Ulocentra, from southeastern United States. Tulane Studies in Zoology and Botany

$723 \quad 29: 1-28$.

724 Suttkus, R.D., R.M. Bailey and H.L. Bart Jr. 1994. Three new species of Etheostoma, subgenus

725 Ulocentra, from the Gulf Coastal Plain of southeastern United States. Tulane Studies in

726 Zoology and Botany 29:97-126.

727 Thompson, D.E. 2011. Geologic Map of Mississippi. Mississippi Department of Environmental

728 Quality. https://www.mdeq.ms.gov/geology/work-areas/surface-geology/.

729 Thompson, K.W. and R.J. Muncy. 1986. Darters of the Little Tallahatchie watershed in northern

730 Mississippi. Journal of the Mississippi Academy of Sciences 31:63-77.

731 USFWS. 2020. Yazoo Darter habitat conservation on working lands in Mississippi. Webpage:

732 https://www.fws.gov/southeast/articles/yazoo-darter-habitat-conservation-on-working-lands-

733 in-mississippi/, accessed 26 February 2020.

734 Warren, M.L., Jr., W.R. Haag and S.B. Adams. 2002. Forest linkages to diversity and abundance

735 in lowland stream fish communities. In: Proceedings of a conference on sustainability of

736 wetlands and water resources: how well can riverine wetlands continue to support society into

737 the 21st century?, pp. 168-182. M.M. Holland, M.L. Warren Jr. and J.A. Stanturf, Eds.

738 USDA Forest Service, Southern Research Station, General Technical Report SRS-50,

739 Asheville, NC. https://www.fs.usda.gov/treesearch/pubs/20170. 


\section{Figure 1}

Map of the distribution of Etheostoma raneyi (Yazoo Darter) and E. faulkneri (Yoknapatawpha Darter) in northern Mississippi.

Distribution is indicated by green circles in the Little Tallahatchie River drainage (E. raneyi) and green triangles in the Yocona River drainage (E. faulkneri). The location of the old confluence (blue square) of the two drainages is shown as well as the new confluence (blue diamond) after stream alterations; the approximate boundaries of the Mississippi Alluvial Plain, Lower Gulf Coastal Plain, and Upper Gulf Coastal Plain are indicated from west to east, respectively. 


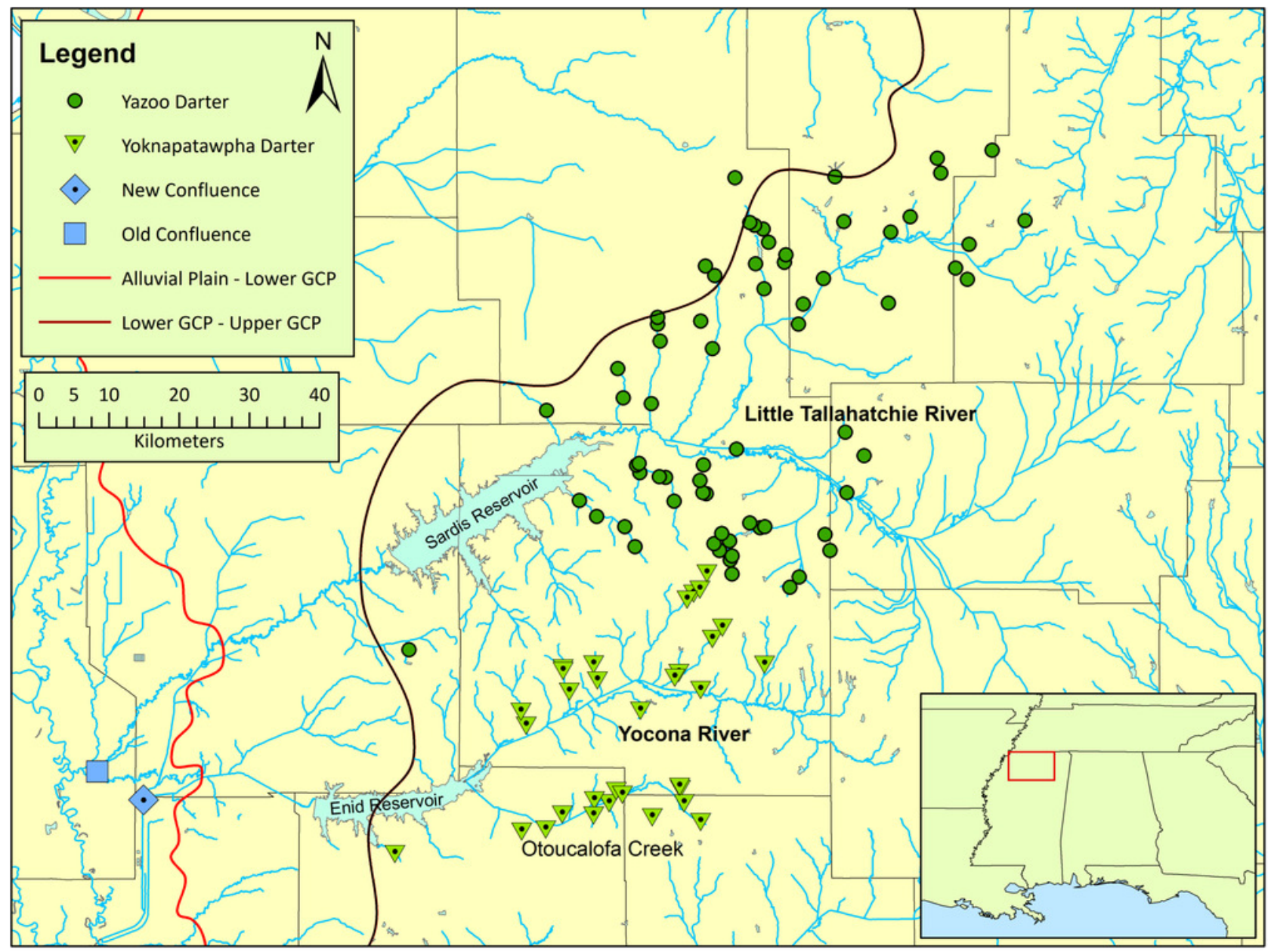


Figure 2

Location of landmarks used for truss measurements (after Powers \& Mayden, 2003).

Numbers correspond to Table 10 .

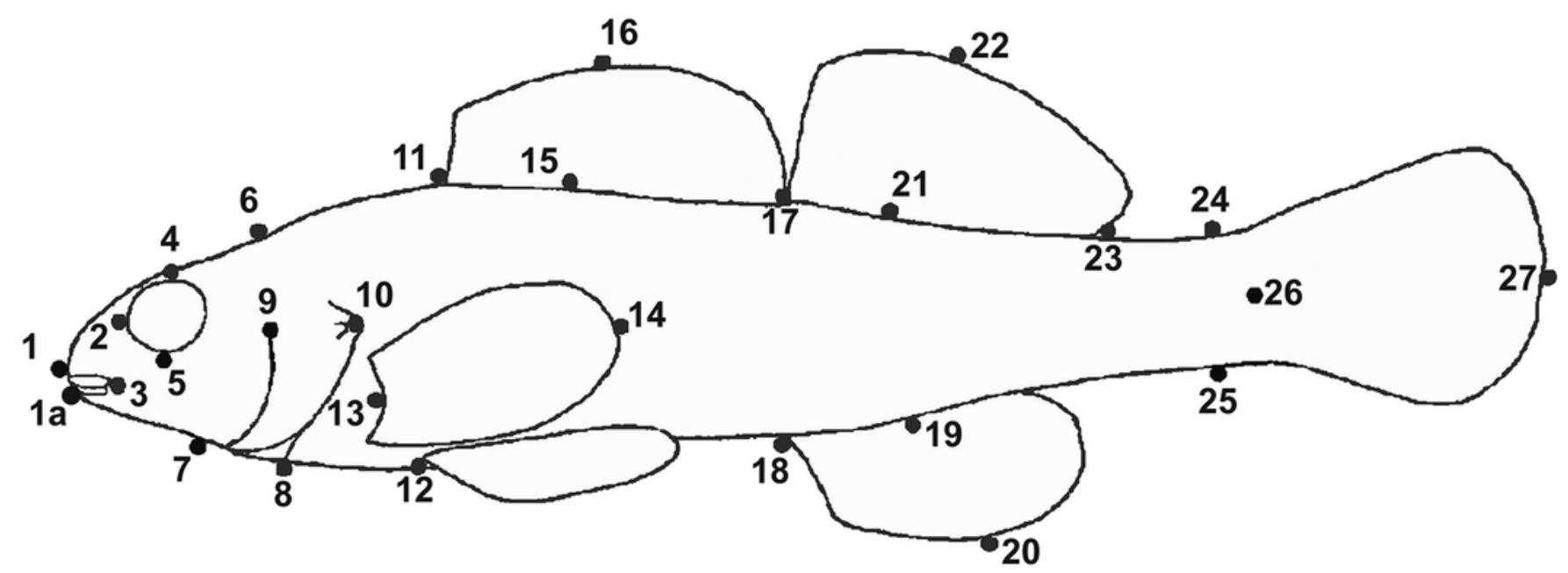


Figure 3

Landmark locations used for geometric morphological analyses (GMA).

The label Y1 in the photograph indicates individual number one from the Yocona River drainage.

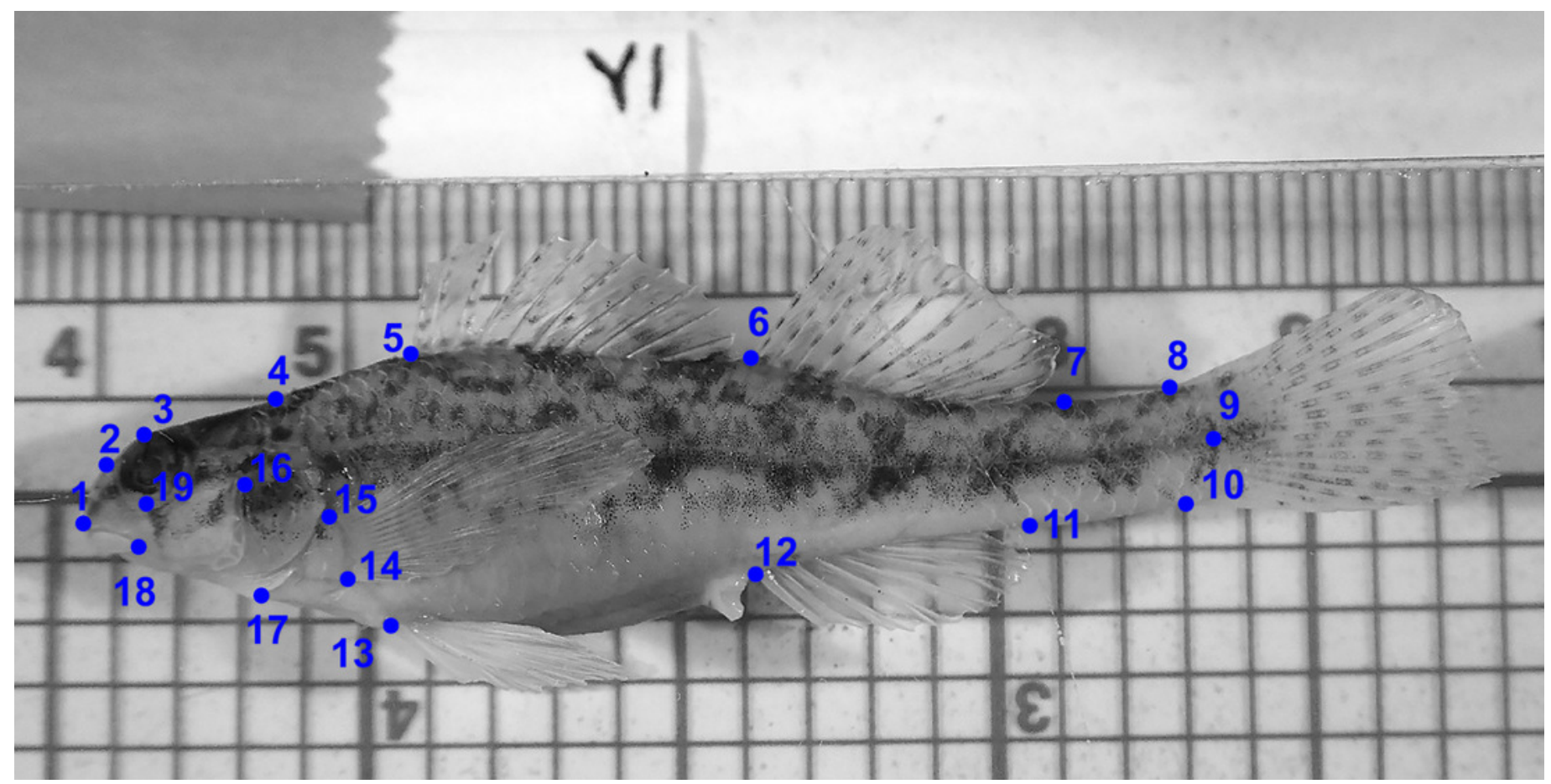


Figure 4

Photographs of Etheostoma faulkneri (Yoknapatawpha Darter) and E. raneyi (Yazoo Darter).

Letters correspond to $E$. faulkneri female allotype (a), female E. raneyi (b), E. faulkneri male holotype (c), and male $E$. raneyi (d); scale bar $=1 \mathrm{~cm}$. 

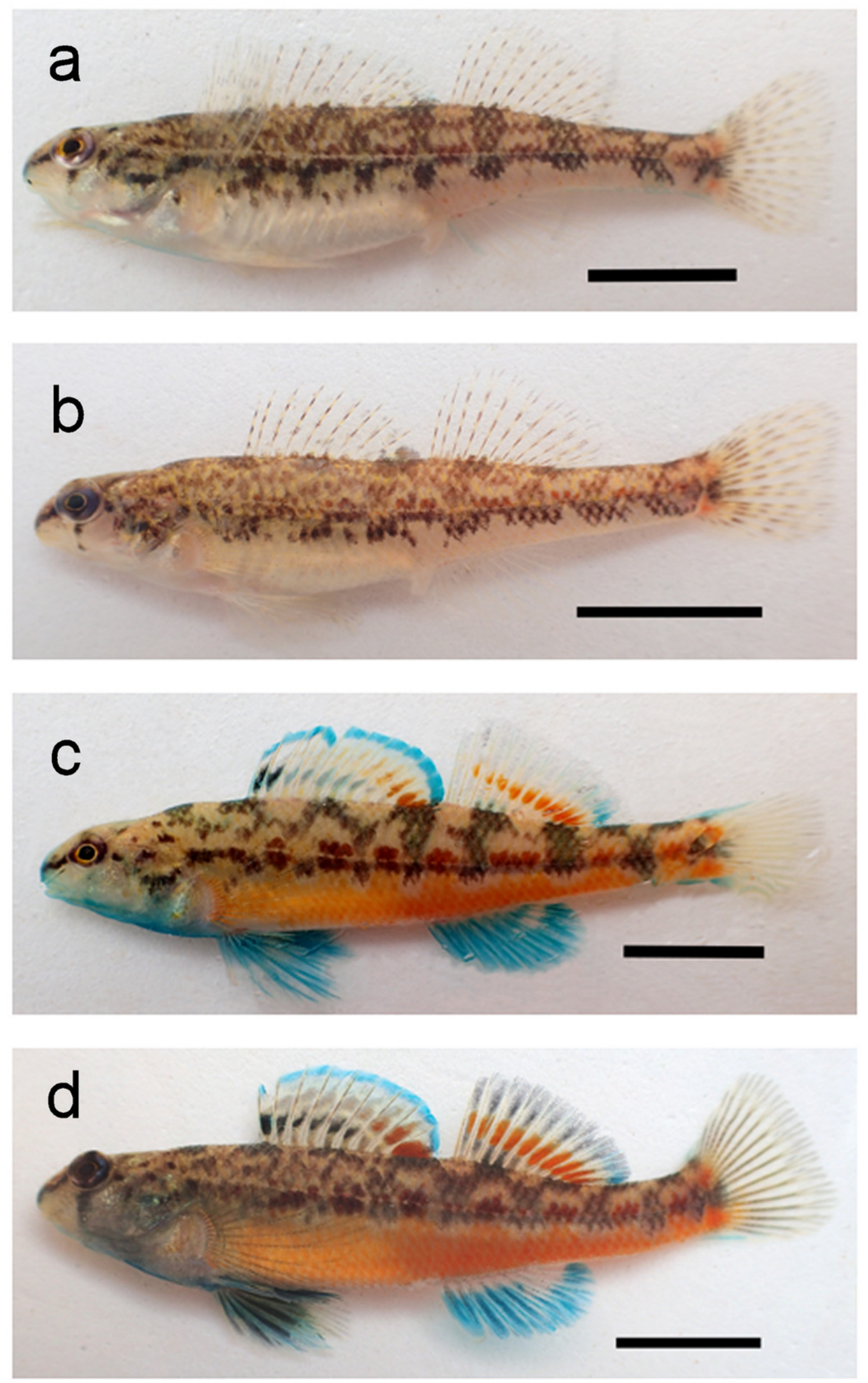


\section{Figure 5}

Bar graph of the results of male nuptial color surveys.

Each graph $(a, b, c)$ represents mean values ( $\pm 95 \%$ C.I.) scored by one of three colleagues for each character (Black, Blue, Window, see text for definitions of characters); L.T.R. = Little Tallahatchie River, $\mathrm{n}=153$; Y.R. = Yocona River, $\mathrm{n}=108$. 

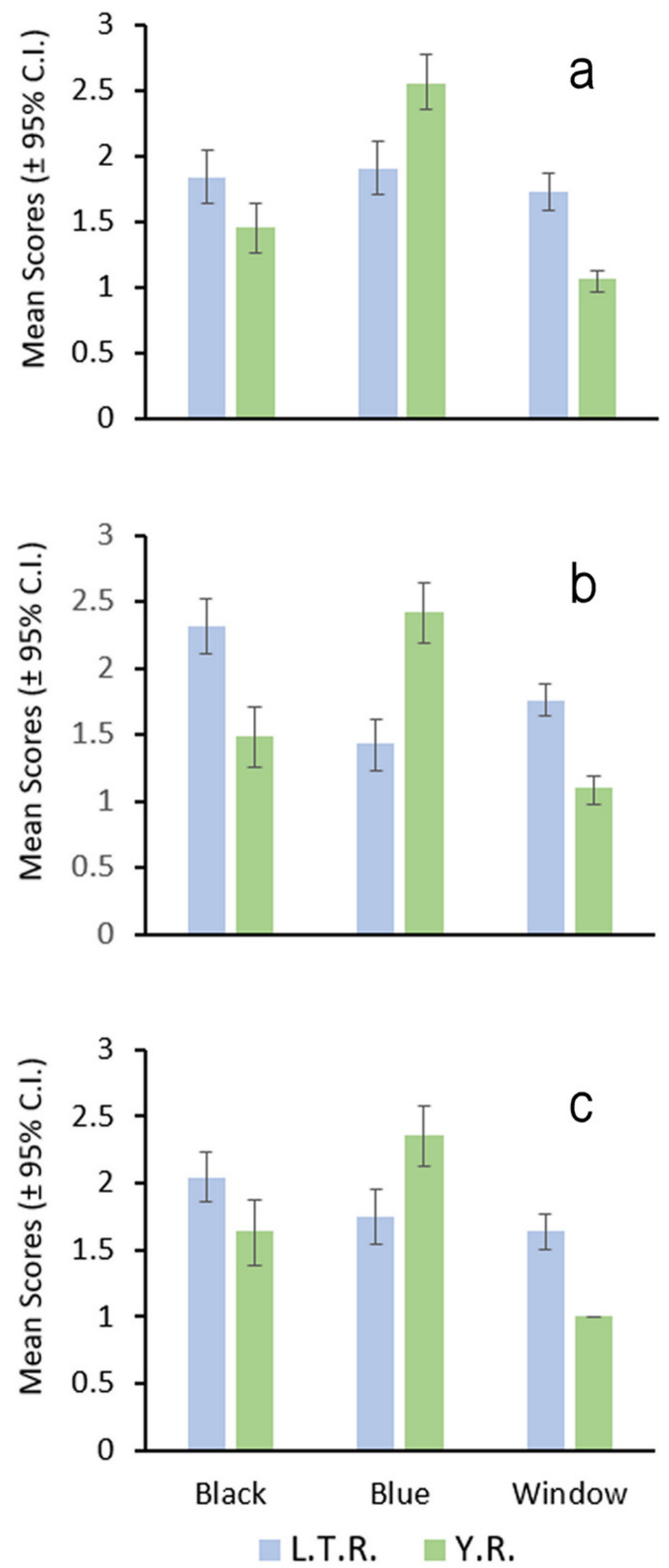
Figure 6

Results from lateral view geometric morphological analyses (GMA, MorphoJ) indicating shape changes for male (a) and female (b) Etheostoma raneyi and E. faulkneri between drainages.

Numbers represent fixed points in the analysis (see Figure 3).

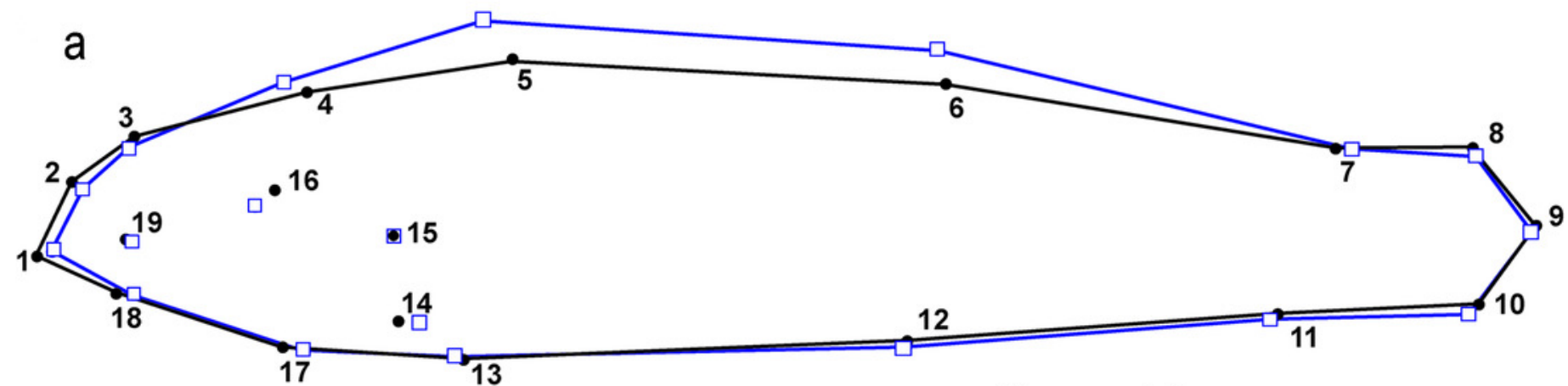

$\square$ Yocona River

- Little Tallahatchie River

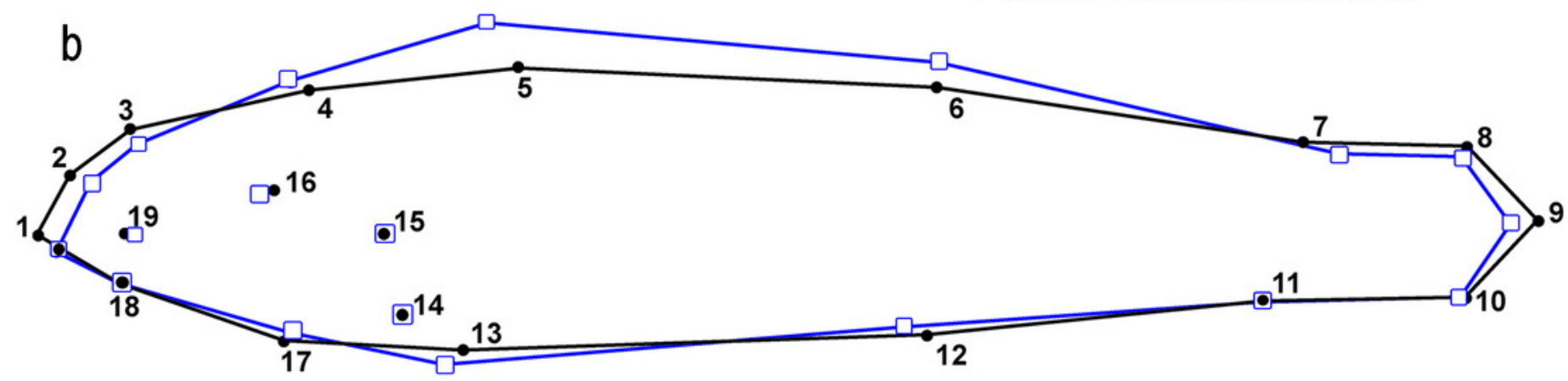


Figure 7

Results from lateral view geometric morphological analyses (GMA) indicating shape changes for male and female Etheostoma raneyi (a)(Little Tallahatchie River) and $E$. faulkneri (b) (Yocona River) between sexes within drainages.

Numbers represent fixed points in the analysis (see Figure 3).

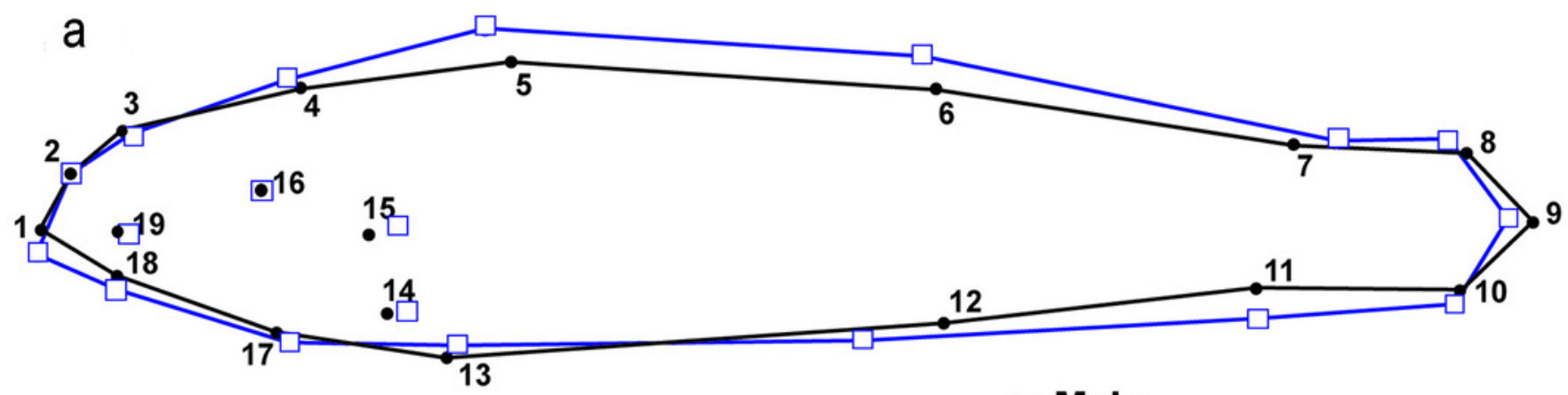

$\square$ Male

- Female

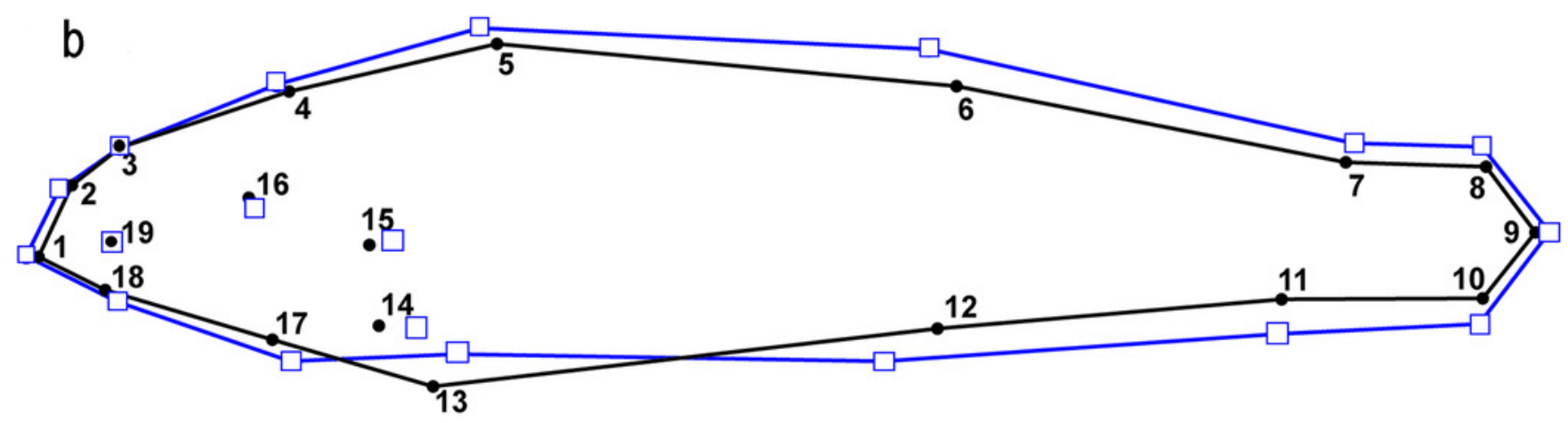


Figure 8

Mean watershed area (a) and stream gradient (b) ( $\pm 95 \%$ C.I.) for all tributary streams with Etheostoma raneyi and E. faulkneri.

Abbreviations indicate Y.R. = Yocona River and L.T.R. = Little Tallahatchie River drainages. 

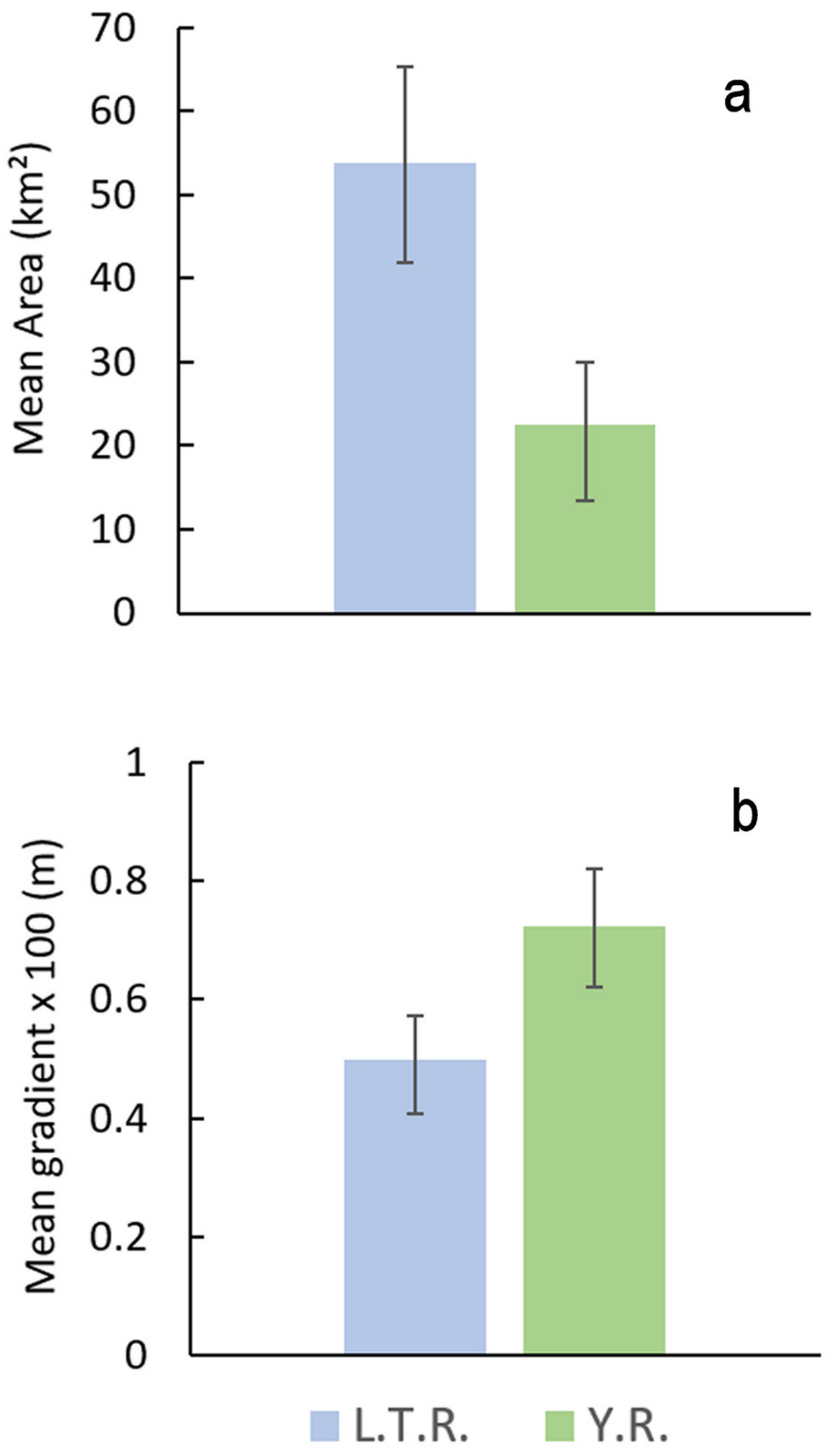


\section{Table 1 (on next page)}

Specimen data used for male nuptial color comparisons.

Stream name, date of sample, water temperature, and the number of males photographed are indicated; L.T.R. $=$ Little Tallahatchie River (Etheostoma raneyi) and Y.R. $=$ Yocona River (E. faulkneri); 


\begin{tabular}{cllccc}
\hline Drainage & Stream & Date & Temp. $\left({ }^{\circ} \mathrm{C}\right)$ & $\mathrm{n}$ & Coordinates \\
\hline L.T.R. & Bay Springs Branch & $2 / 23 / 2017$ & 15 & 12 & $34.428,-89.395$ \\
L.T.R. & Hurricane Creek & $3 / 16 / 2017$ & 9.5 & 7 & $34.425,-89.496$ \\
L.T.R. & Yellow Rabbit Creek & $4 / 7 / 2017$ & 14 & 7 & $34.819,-89.106$ \\
L.T.R. & Big Spring Creek & $4 / 17 / 2017$ & 16 & 9 & $34.664,-89.413$ \\
L.T.R. & Chewalla Creek & $3 / 22 / 2018$ & 8.5 & 7 & $34.725,-89.305$ \\
L.T.R. & Chewalla Creek & $3 / 22 / 2018$ & 13 & 5 & $34.76,-89.333$ \\
L.T.R. & Graham Mill Creek & $3 / 22 / 2018$ & 13 & 4 & $34.503,-89.491$ \\
\hline & Total & & & 51 & \\
\hline Y.R. & Morris Creek & $2 / 24 / 2017$ & 15 & 12 & $34.282,-89.544$ \\
Y.R. & Morris Creek & $3 / 8 / 2018$ & 11.5 & 5 & $34.282,-89.544$ \\
Y.R. & Morris Creek & $4 / 1 / 2018$ & 15.5 & 3 & $34.282,-89.544$ \\
Y.R. & Johnson Creek & $4 / 6 / 2017$ & 14 & 5 & $34.124,-89.641$ \\
Y.R. & Gordon Branch & $4 / 6 / 2017$ & 13 & 1 & $34.14,-89.549$ \\
Y.R. & Mill Creek & $1 / 1 / 2017$ & - & 3 & $34.167,-89.52$ \\
Y.R. & Mill Creek & $3 / 8 / 2018$ & 9.5 & 5 & $34.167,-89.52$ \\
Y.R. & U.T. Otoucalofa Creek & $3 / 23 / 2018$ & 11 & 2 & $34.126,-89.611$ \\
\hline & Total & & & 36 & \\
\hline
\end{tabular}

1 


\section{Table 2 (on next page)}

Specimen data used for geometric morphological analyses (MorphoJ).

Locations and sample sizes for collections by drainage are indicated: L.T.R. $=$ Little

Tallahatchie River (Etheostoma raneyi); Y.R. = Yocona River (E. faulkneri); U.T. = unnamed tributary). 


\begin{tabular}{|c|c|c|c|c|}
\hline Drainage & Stream & Coordinates & Male $\mathrm{n}$ & Female $\mathrm{n}$ \\
\hline L.T.R. & Yellow Rabbit Creek & $34.819,-89.106$ & 6 & 5 \\
\hline L.T.R. & Chewalla Creek & $34.726,-89.305$ & 13 & 7 \\
\hline L.T.R. & Bay Springs Branch & $34.428,-89.395$ & 8 & 0 \\
\hline L.T.R. & Big Spring Creek & $34.664,-89.413$ & 12 & 9 \\
\hline L.T.R. & Shelby Creek & $34.844,-89.039$ & 1 & 2 \\
\hline L.T.R. & Fice Creek & $34.421,-89.247$ & 1 & 1 \\
\hline L.T.R. & U.T. Tippah River & $34.682,-89.281$ & 1 & 1 \\
\hline L.T.R. & U.T. Tippah River & $34.712,-89.254$ & 0 & 4 \\
\hline L.T.R. & Oak Chewalla & $34.583,-89.511$ & 0 & 2 \\
\hline L.T.R. & Chilli Creek & $34.682,-89.173$ & 0 & 1 \\
\hline L.T.R. & Mitchell Creek & $34.521,-89.203$ & 0 & 1 \\
\hline L.T.R. & Puskus Creek & $34.447,-89.345$ & 1 & 5 \\
\hline L.T.R. & Cypress Creek & $34.383,-89.299$ & 5 & 6 \\
\hline L.T.R. & Lee Creek & $34.498,-89.457$ & 0 & 1 \\
\hline L.T.R. & Wagner Creek & $34.768,-89.229$ & 2 & 2 \\
\hline \multirow[t]{2}{*}{ L.T.R. } & Hurricane Creek & $34.425,-89.496$ & 2 & 6 \\
\hline & Total & & 52 & 53 \\
\hline Y.R. & Johnson Creek & $34.124,-89.641$ & 0 & 1 \\
\hline Y.R. & Morris Creek & $34.282,-89.544$ & 4 & 9 \\
\hline Y.R. & Mill Creek & $34.167,-89.52$ & 5 & 1 \\
\hline Y.R. & Gordon Branch & $34.14,-89.549$ & 9 & 4 \\
\hline Y.R. & Yellow Leaf Creek & $34.376,-89.421$ & 2 & 5 \\
\hline Y.R. & Pumpkin Creek & $34.285,-89.445$ & 14 & 9 \\
\hline Y.R. & U.T. Otoucalofa Creek & $34.126,-89.611$ & 6 & 19 \\
\hline Y.R. & Taylor Creek & $34.297,-89.589$ & 3 & 6 \\
\hline Y.R. & Smith Creek & $34.168,-89.439$ & 1 & 0 \\
\hline \multirow[t]{2}{*}{ Y.R. } & Splinter Creek & $34.236,-89.635$ & 5 & 6 \\
\hline & Total & & 49 & 60 \\
\hline
\end{tabular}




\section{Table 3 (on next page)}

Compilation of frequency distributions of lateral line scale counts for six species of snubnose darters and one undescribed form.

Modal counts are in bold; sources of data not cited in the table are: Etheostoma cervus (Bailey \& Etnier, 1988; Powers \& Mayden, 2003; Kozal et al., 2017); E. pyrrhogaster, E.

zonistium, E. cf. zonistium, and E. cyanoprosopum (Bailey \& Etnier, 1988; Kozal et al., 2017); S.D. = standard deviation . 


\begin{tabular}{|c|c|c|c|c|c|c|c|c|c|c|c|c|c|c|c|c|c|c|c|c|c|}
\hline & 36 & 37 & 38 & 39 & 40 & 41 & 42 & 43 & 44 & 45 & 46 & 47 & 48 & 49 & 50 & 51 & 52 & 53 & $\mathrm{n}$ & $\square$ & S.D. \\
\hline E. cervus & 2 & 11 & 30 & 49 & 40 & 29 & 8 & 3 & & 2 & & & & & & & & & 174 & 39.5 & 1.51 \\
\hline E. pyrrhogaster & & & & 8 & 10 & 40 & 44 & 47 & 26 & 13 & 10 & 3 & & & & & & & 201 & 42.5 & 1.73 \\
\hline E. zonistium (Tennessee R.) & & & & & 5 & 7 & 18 & 38 & 45 & 61 & 85 & 65 & 50 & 50 & & & & & 424 & 45.8 & 2.13 \\
\hline E. cf. zonistium (Hatchie R.) & & & & & & 5 & 5 & 6 & 12 & 33 & 22 & 15 & 15 & 5 & 2 & 1 & 1 & & 122 & 45.7 & 2.11 \\
\hline E. cyanoprosopum & & & & & & & & & 1 & 2 & 11 & 18 & 31 & 23 & 15 & 11 & 3 & 2 & 117 & 48.5 & 1.73 \\
\hline E. raneyi (Suttkus et al., 1994) & & & & & & 1 & 7 & 15 & 24 & 34 & 25 & 32 & 11 & 11 & 1 & 2 & 1 & 1 & 165 & 45.7 & 2.09 \\
\hline E. faulkneri (Kozal et al., 2017) & & & & & & & & & 5 & 10 & 7 & 5 & 4 & 4 & 1 & & & & 36 & 46.3 & 1.70 \\
\hline E. raneyi (new data) & & & & & & & 3 & 3 & 9 & 19 & 21 & 34 & 21 & 19 & 15 & 7 & 1 & & 152 & 47.2 & 2.10 \\
\hline E. faulkneri (new data) & & & & & & 1 & 5 & 6 & 16 & 29 & 22 & 19 & 13 & 7 & 1 & 1 & & & 120 & 45.8 & 1.88 \\
\hline
\end{tabular}




\section{Table 4 (on next page)}

Compilation of frequency distributions of transverse scale counts for six species of snubnose darters and one undescribed form.

Modal counts are in bold; sources of data not cited in the table are: Etheostoma cervus

(Powers \& Mayden, 2003; Kozal et al., 2017); E. pyrrhogaster, E. zonistium, E. cf. zonistium, and E. cyanoprosopum (Kozal et al., 2017); S.D. = standard deviation. 


\begin{tabular}{lcccccccccccc}
\hline & 10 & 11 & 12 & 13 & 14 & 15 & 16 & 17 & 18 & $\mathrm{n}$ & $\square$ & S.D. \\
\hline E. cervus & 3 & 20 & $\mathbf{3 2}$ & 11 & 3 & & & & & 69 & 11.9 & 0.89 \\
E. pyrrhogaster & 1 & $\mathbf{1 6}$ & $\mathbf{8}$ & $\mathbf{1}$ & 1 & & & & & 27 & 11.4 & 0.80 \\
E. zonistium (Tennessee R.) & & & 27 & $\mathbf{8 2}$ & 63 & 9 & & & & 181 & 13.3 & 0.78 \\
E. cf. zonistium (Hatchie R.) & 4 & $\mathbf{4 7}$ & $\mathbf{7}$ & $\mathbf{1}$ & & & & & & 59 & 11.1 & 0.50 \\
E. cyanoprosopum & & & 3 & 13 & 21 & $\mathbf{3 5}$ & 6 & 1 & 3 & 82 & 14.5 & 1.21 \\
& & & & & & & & & & & & \\
E. raneyi (Suttkus et al., 1994) & 2 & 36 & $\mathbf{5 7}$ & 51 & 16 & 3 & & & 165 & 13.3 & 1.02 \\
E. faulkneri (Kozal et al., 2017) & 9 & 10 & $\mathbf{1 7}$ & & & & & & 36 & 13.7 & 5.34 \\
E. raneyi (new data) & 17 & 42 & $\mathbf{7 5}$ & 19 & & & & & 153 & 12.6 & 0.84 \\
E. faulkneri (new data) & 2 & 38 & $\mathbf{6 1}$ & 19 & 1 & & & & 121 & 12.8 & 0.74
\end{tabular}

1 


\section{Table 5 (on next page)}

Compilation of frequency distributions of caudal peduncle scale counts for six species of snubnose darters and one undescribed form.

Modal counts are in bold; sources of data not cited in the table are: Etheostoma cervus (Bailey \& Etnier, 1988; Powers \& Mayden, 2003; Kozal et al., 2017); E. pyrrhogaster, E.

zonistium, E. cf. zonistium, and E. cyanoprosopum (Bailey \& Etnier, 1988; Kozal et al., 2017); S.D. = standard deviation . 


\begin{tabular}{lcccccccccc}
\hline & 14 & 15 & 16 & 17 & 18 & 19 & 20 & $\mathrm{n}$ & $\square$ & S.D. \\
\hline E. cervus & 2 & 9 & 35 & $\mathbf{6 9}$ & 17 & 1 & 1 & 134 & 16.7 & 0.90 \\
E. pyrrhogaster & 4 & 18 & $\mathbf{1 9}$ & 14 & 1 & & & 56 & 15.8 & 0.96 \\
E. zonistium (Tennessee R.) & & 6 & 38 & $\mathbf{1 4 8}$ & 68 & 32 & 2 & 294 & 17.3 & 0.92 \\
E. cf. zonistium (Hatchie R.) & 2 & 18 & $\mathbf{4 1}$ & 36 & & & & 97 & 16.1 & 0.79 \\
E. cyanoprosopum & & & 5 & $\mathbf{4 5}$ & 28 & 26 & 8 & 112 & 17.9 & 1.05 \\
& & & & & & & & & & \\
E. raneyi (Suttkus et al., 1994) & & 16 & 57 & $\mathbf{7 5}$ & 13 & 4 & & 165 & 16.6 & 0.86 \\
E. faulkneri (Kozal et al., 2017) & & 9 & $\mathbf{1 5}$ & 10 & 1 & & & 35 & 16.1 & 0.82 \\
E. raneyi (new data) & 1 & 11 & 37 & $\mathbf{6 6}$ & 30 & 4 & & 149 & 16.8 & 0.94 \\
E. faulkneri (new data) & & & 9 & $\mathbf{5 9}$ & 29 & 11 & & 108 & 17.4 & 0.78
\end{tabular}




\section{Table 6(on next page)}

Compilation of frequency distributions of first dorsal fin spine counts for six species of snubnose darters and one undescribed form.

Modal counts are in bold; sources of data not cited in the table are: Etheostoma cervus (Bailey \& Etnier, 1988; Powers \& Mayden, 2003; Kozal et al., 2017); E. pyrrhogaster, E.

zonistium, E. cf. zonistium, and E. cyanoprosopum (Bailey \& Etnier, 1988; Kozal et al., 2017); S.D. = standard deviation . 


\begin{tabular}{lccccccc}
\hline & 9 & 10 & 11 & 12 & $\mathrm{n}$ & $\square$ & S.D. \\
\hline E. cervus & & 59 & $\mathbf{7 6}$ & 1 & 136 & 10.6 & 0.51 \\
E. pyrrhogaster & 8 & $\mathbf{4 2}$ & 27 & 1 & 78 & 10.3 & 0.66 \\
E. zonistium (Tennessee R.) & 20 & $\mathbf{2 5 2}$ & 96 & 2 & 370 & 10.2 & 0.54 \\
E. cf. zonistium (Hatchie R.) & 8 & $\mathbf{9 9}$ & 15 & & 122 & 10.1 & 0.43 \\
E. cyanoprosopum & 4 & $\mathbf{6 0}$ & 48 & 2 & 114 & 10.4 & 0.59 \\
& & & & & & & \\
E. raneyi (Suttkus et al., 1994) & 14 & $\mathbf{1 1 4}$ & 35 & 2 & 165 & 10.2 & 0.57 \\
E. faulkneri (Kozal et al., 2017) & 2 & $\mathbf{3 1}$ & 3 & & 36 & 10.0 & 0.38 \\
E. raneyi (new data) & 18 & $\mathbf{1 1 1}$ & 24 & & 153 & 10.0 & 0.52 \\
E. faulkneri (new data) & 8 & $\mathbf{8 6}$ & 21 & & 115 & 10.1 & 0.49
\end{tabular}

1 


\section{Table 7 (on next page)}

Compilation of frequency distributions of second dorsal fin ray counts for six species of snubnose darters and one undescribed form.

Modal counts are in bold; sources of data not cited in the table are: Etheostoma cervus (Bailey \& Etnier, 1988; Powers \& Mayden, 2003; Kozal et al., 2017); E. pyrrhogaster, E.

zonistium, E. cf. zonistium, and E. cyanoprosopum (Bailey \& Etnier, 1988; Kozal et al., 2017); S.D. = standard deviation . 


\begin{tabular}{lcccccccc}
\hline & 9 & 10 & 11 & 12 & 13 & $\mathrm{n}$ & $\square$ & S.D. \\
\hline E. cervus & & & $\mathbf{5 3}$ & 40 & 4 & 97 & 11.5 & 0.58 \\
E. pyrrhogaster & & & $\mathbf{4 1}$ & 34 & 3 & 78 & 11.5 & 0.58 \\
E. zonistium (Tennessee R.) & 3 & 58 & $\mathbf{2 4 9}$ & 59 & & 369 & 11.0 & 0.59 \\
E. cf. zonistium (Hatchie R.) & 1 & 21 & $\mathbf{6 8}$ & 2 & & 92 & 10.8 & 0.49 \\
E. cyanoprosopum & 2 & 26 & $\mathbf{8 1}$ & 3 & & 112 & 10.8 & 0.52 \\
& & & & & & & & \\
E. raneyi (Suttkus et al., 1994) & 1 & 50 & $\mathbf{1 0 5}$ & 9 & & 165 & 10.7 & 0.56 \\
E. faulkneri (Kozal et al., 2017) & & 5 & $\mathbf{2 8}$ & 3 & & 36 & 10.9 & 0.47 \\
E. raneyi (new data) & 3 & 57 & $\mathbf{8 6}$ & 6 & & 152 & 10.6 & 0.60 \\
E. faulkneri (new data) & 1 & 53 & $\mathbf{6 1}$ & & & 115 & 10.5 & 0.52
\end{tabular}

1 


\section{Table 8(on next page)}

Compilation of frequency distributions of anal fin ray counts for six species of snubnose darters and one undescribed form.

Modal counts are in bold; sources of data not cited in the table are: Etheostoma cervus (Bailey \& Etnier, 1988; Powers \& Mayden, 2003; and Kozal et al., 2017); E. pyrrhogaster, E. zonistium, E. cf. zonistium, and E. cyanoprosopum (Bailey \& Etnier, 1988; Kozal et al., 2017); S.D. = standard deviation. 


\begin{tabular}{lcccccccc}
\hline & 5 & 6 & 7 & 8 & 9 & $\mathrm{n}$ & $\square$ & S.D. \\
\hline E. cervus & & 2 & $\mathbf{7 4}$ & 58 & 2 & 136 & 7.4 & 0.55 \\
E. pyrrhogaster & & & 18 & $\mathbf{5 2}$ & 8 & 78 & 7.9 & 0.57 \\
E. zonistium (Tennessee R.) & 2 & 30 & $\mathbf{2 6 0}$ & 54 & 1 & 347 & 7.1 & 0.52 \\
E. cf. zonistium (Hatchie R.) & & 23 & $\mathbf{6 4}$ & 5 & & 92 & 6.8 & 0.52 \\
E. cyanoprosopum & 10 & $\mathbf{7 0}$ & 34 & & 114 & 7.2 & 0.59 \\
& & & & & & & \\
E. raneyi (Suttkus et al., 1994) & 11 & $\mathbf{1 3 3}$ & 21 & & 165 & 7.1 & 0.44 \\
E. faulkneri (Kozal et al., 2017) & 2 & $\mathbf{2 6}$ & 8 & & 36 & 7.2 & 0.51 \\
E. raneyi (new data) & & 11 & $\mathbf{9 9}$ & 9 & & 119 & 7.0 & 0.41 \\
E. faulkneri (new data) & 7 & $\mathbf{8 6}$ & 9 & & 102 & 7.0 & 0.40 \\
& & & & & & & &
\end{tabular}

1 


\section{Table 9 (on next page)}

Compilation of frequency distributions of pectoral fin ray counts for six species of snubnose darters and one undescribed form.

Modal counts are in bold; sources of data not cited in the table are: Etheostoma cervus (Bailey \& Etnier, 1988; Powers \& Mayden, 2003; Kozal et al., 2017); E. pyrrhogaster, E.

zonistium, E. cf. zonistium, and E. cyanoprosopum (Bailey \& Etnier, 1988; Kozal et al., 2017); S.D. = standard deviation . 


\begin{tabular}{lcccccccc}
\hline & 12 & 13 & 14 & 15 & 16 & $\mathrm{n}$ & $\square$ & S.D. \\
\hline E. cervus & & 20 & $\mathbf{7 2}$ & 5 & & 97 & 13.8 & 0.49 \\
E. pyrrhogaster & & 27 & $\mathbf{4 1}$ & & & 68 & 13.6 & 0.49 \\
E. zonistium (Tennessee R.) & 1 & 98 & $\mathbf{3 2 8}$ & 63 & & 490 & 13.9 & 0.58 \\
E. cf. zonistium (Hatchie R.) & & 38 & $\mathbf{8 3}$ & 1 & & 122 & 13.7 & 0.48 \\
E. cyanoprosopum & 1 & 8 & $\mathbf{8 7}$ & 18 & & 114 & 14.1 & 0.50 \\
& & & & & & & & \\
E. raneyi (Suttkus et al., 1994) & & 11 & $\mathbf{1 2 6}$ & 28 & & 165 & 14.1 & 0.48 \\
E. faulkneri (Kozal et al., 2017) & & 3 & $\mathbf{2 8}$ & 4 & 1 & 36 & 14.1 & 0.55 \\
E. raneyi (new data) & & 11 & $\mathbf{8 6}$ & 15 & & 112 & 14.0 & 0.48 \\
E. faulkneri (new data) & & 10 & $\mathbf{8 0}$ & 10 & & 100 & 14.0 & 0.45
\end{tabular}

1 


\section{Table $\mathbf{1 0}$ (on next page)}

Means and 95\% confidence intervals (C.I.) for measurements of morphometric truss variables in thousandths of SL (except for SL) for Etheostoma faulkneri and E. raneyi males and females.

Variable labels correspond to landmarks in Figure 2; measurements in bold font with asterisks indicate that $95 \%$ confidence intervals do not overlap within sexes between drainages. 


\begin{tabular}{|c|c|c|c|c|}
\hline \multirow{2}{*}{ Variable } & E. faulkneri males $(n=43)$ & E. raneyi males $(n=68)$ & E. faulkneri females $(n=51)$ & E. raneyi females $(n=77)$ \\
\hline & mean (95\% C.I.) & mean (95\% C.I.) & mean (95\% C.I.) & mean (95\% C.I.) \\
\hline SL & *42.9 (41.3-44.6) & *39.7 (38.4-41.1) & *39.3 (38.4-40.1) & *37.3 (36.3-38.3) \\
\hline $1-3$ & *63 (62.6-64.9) & *67.6 (66.5-68.5) & $* 61.2(60.3-62)$ & $* 66(65.2-66.8)$ \\
\hline $1 a-3$ & *56.5 (55.1-57.8) & *59.6 (58.6-60.6) & *54.2 (53.4-55.1) & *58.4 (57.5-59.4) \\
\hline $1-1 a$ & $7.3(6.3-8.4)$ & $7.9(7.3-8.6)$ & $6.9(6.4-7.5)$ & 7.6 (7.1-8.1) \\
\hline 3-3 & $73.1(71.4-74.9)$ & $70.7(69.3-72)$ & $66.8(65.5-68)$ & $68.8(67.8-69.8)$ \\
\hline $1-2$ & *47.4 (45.9-48.9) & *51.8 (50.3-53.2) & *45.6 (44-46.9) & *48.6 (47.4-49.7) \\
\hline 3-5 & $36(34.4-37.7)$ & $36(34.5-37.7)$ & $30.6(29.3-31.9)$ & $32.2(30.7-33.8)$ \\
\hline $1-9$ & *159.2 (157-161.3) & *164.8 (162.8-166.9) & *156.9 (155.2-158.5) & *162.8 (160.8-164.7) \\
\hline $9-10$ & $88.2(86.3-90.2)$ & $89.3(87.8-90.7)$ & $84.4(83-85.9)$ & $84.3(83-85.6)$ \\
\hline $4-4$ & $44.1(43.1-45.1)$ & $45.8(44.9-46.8)$ & $* 42.1(40.9-43.2)$ & $* 45.6(44.9-46.4)$ \\
\hline $13-13$ & $141.9(138.2-145.7)$ & 139.7 (137.5-141.8) & *145.4 (142.6-148.3) & *137.6 (135.3-139.8) \\
\hline $13-14$ & $272(266.3-277)$ & 272.7 (269.5-275.9) & $271.7(268-275.2)$ & $271.7(269-274.5)$ \\
\hline $15-16$ & 137 (134-139.8) & $140.3(138.1-142.6)$ & $126.7(124.2-129.1)$ & $129.9(120.5-133.5)$ \\
\hline $19-20$ & $118.7(115-122.2)$ & $121.4(118.3-124.7)$ & 118.5 (115.7-121.4) & 117.1 (114.5-119.7) \\
\hline $21-22$ & $155.1(151.7-158.5)$ & $154.1(151.6-156.5)$ & $152.4(149.3-155.3)$ & $151.7(149.6-153.7)$ \\
\hline $23-24$ & $217.1(214-220.1)$ & $216.2(211.7-220.8)$ & $215.5(211.3-219.5)$ & 218.1 (214.9-220.9) \\
\hline $24-25$ & $104.2(102.4-106)$ & $101.5(100.3-102.7)$ & $94.7(93.5-96)$ & $95.8(94.9-96.7)$ \\
\hline $26-27$ & $222.4(218.9-225.7)$ & 227.9 (224.2-231.9) & $227.6(224.6-230.5)$ & $226.6(224.3-229)$ \\
\hline $1-6$ & *196.3 (194.6-197.9) & $* 204.2(202.4-206)$ & *195.7 (194.3-197.1) & *202.2 (200.6-203.8) \\
\hline $1-7$ & *106.6 (102.9-110.1) & *122.8 (120.4-125.2) & *110.4 (107.4-113.4) & *117.3 (115.2-119.3) \\
\hline $6-11$ & $143.7(141.5-145.9)$ & $142.4(140.6-144.3)$ & $145.3(143-147.8)$ & $142.9(141.3-144.5)$ \\
\hline $7-12$ & *183.4 (179.9-187) & *175.8 (172.4-179.2) & 176.5 (172.9-179.9) & 179 (175.7-182.4) \\
\hline $11-12$ & *212.7 (208.5-216.9) & *204.3 (201.5-207.1) & *214.8 (210.7-219) & *196.3 (193.7-198.8) \\
\hline $11-17$ & *298.7 (295-302.3) & *287.1 (283.1-291.2) & *286.4 (283.2-289.5) & *270.6 (266.9-274.4) \\
\hline $11-18$ & *344.4 (341.4-347.6) & *335.2 (332-338.4) & *343.5 (340.3-346.7) & *333.5 (330.6-336.5) \\
\hline $12-17$ & $371.5(366.2-376.7)$ & $370.9(367.3-374.5)$ & $377.1(373-381.3)$ & $368.3(364.5-372)$ \\
\hline $17-18$ & *187.2 (183.4-191.2) & *176.9 (174.6-179.3) & $171.3(169-173.6)$ & $167.6(165.8-169.4)$ \\
\hline $17-25$ & $396.3(392.8-399.8)$ & $393.7(390.4-397)$ & 389.7 (386.9-392.6) & 388.7 (386.4-391.1) \\
\hline $18-24$ & $409.6(405.9-413.3)$ & $413.5(410.5-416.5)$ & $401.6(398-405.2)$ & $402.4(399.6-405.2)$ \\
\hline
\end{tabular}

